\title{
Moving Museums: \\ Incorporating Contemporary Dance in \\ New Zealand Museums
}

by

Naiomi Murgatroyd

A dissertation submitted to the Victoria University of Wellington in partial fulfilment of the requirements for the degree of

Master of Museum \& Heritage Studies

Victoria University of Wellington 


\begin{abstract}
Dance has been used historically in museums in both exhibitions and public programmes. These events provide opportunities for museums to collaborate with performing arts institutions. Incorporating contemporary dance in New Zealand museums poses a number of challenges for both the dance company and for the museum; however it can provide a unique and rewarding visitor experience. There has been little research into the use of contemporary dance in the museum environment, or the practicalities of holding such events. The impact of dance performances on the museum visitor has also been neglected.
\end{abstract}

This case study of a contemporary dance company performing in a New Zealand museum investigates the relationship between the two organisations and the impact the performance had on the visitor. Ten interviews were conducted with museum staff, dance company staff and one audience member. This case study provides insight into the relationship between the two institutions as well as the visitor experience.

It was found that significant practical and financial barriers could potentially prevent both the dance company and the museum from holding dance events. Key areas of concern in organising this event were safety, communication and measuring the success of the event. A strong relationship between the institutions and open channels of communication between the staff involved allowed for practical solutions to these issues. The connection between the dance work and the museum exhibition space was questioned by visitors, who did not overtly see a link between the two despite the artistic intentions of the dance company. Nonetheless meaning was taken from the piece in less direct ways. Firstly, visitors generated meaning from the social aspects of their visit. Secondly, they found meaning in the physical environment of the museum. 


\section{Acknowledgements}

Firstly, thank you to my supervisors Dr. Lee Davidson and Brett Mason for your guidance throughout the research process, which was invaluable. Thank you for your encouragement, reassurance and detailed feedback.

This research also would not have been possible without the two organisations who committed to participating in my case study. Thank you to The Museum of Wellington City and Sea and Footnote Dance Company, and to their directors Brett Mason and Dierdre Tarrant respectively, who welcomed my research project with open arms. I am grateful also to all of those people who agreed to be interviewed. Thank you for your time and your thoughtful answers.

Thank you also to my friends and classmates Casimar Larkin, David Luoni, Emily Murray, and everyone else who worked in the post-grad room over the years. You have shared the ups and downs of post-grad life made it a great experience. This also extends to my dear friends Suzanne, Kyle and Adrian, for bearing with me for all the years of hard work and hard partying in between. I must also thank my colleagues at the Museum of Wellington, for covering my shifts to give me time to write. Holla!

The biggest thank you of all goes to my Mum, Dad, my brother Elliot and my dog House. Thank you for the many phone calls and texts of support, deposits of money and trips home for a break. Without your years of constant love and encouragement this dissertation would never have made it onto paper. It is because of you that I have made it this far and will continue to strive for excellence in everything I endeavour to do.

And finally thank you to the Real Hot Bitches Dance Troupe for inspiring me to push it (push it real good). My years in Lycra have constantly reminded me that what I lack in technique I make up for in passion and that, most importantly, "You can't fight your nature". 


\section{Table of Contents}

CHAPTER ONE: INTRODUCTION ................................................................................ 1

INTRODUCTION

LITERATURE REVIEW ...................................................................................... 3

CHAPTER TWO: RESEARCH DESIGN ....................................................................... 25

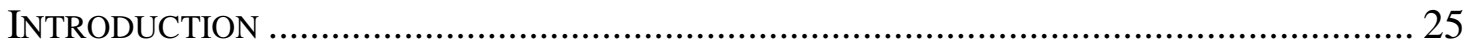

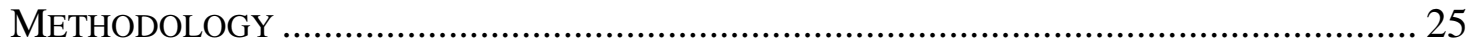

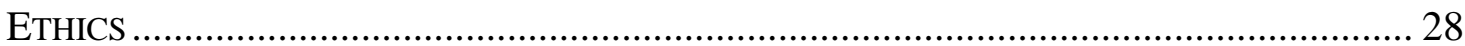

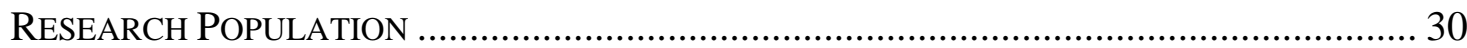

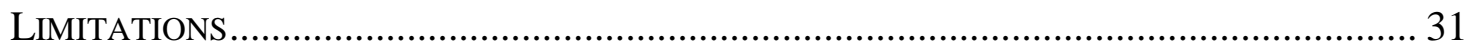

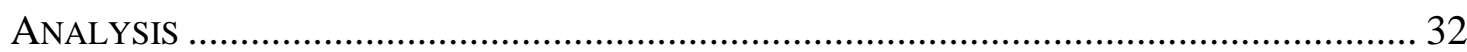

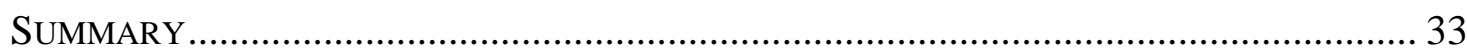

INTRODUCING THE CASE STUDY ……………………………………………..... 34

CHAPTER THREE: FINDINGS ...................................................................................... 38

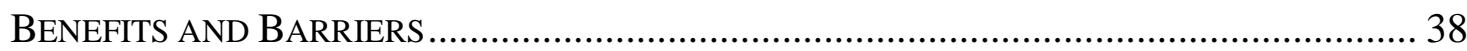

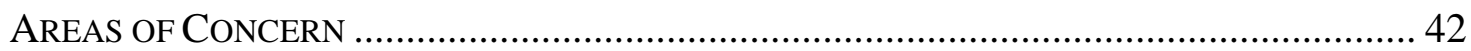

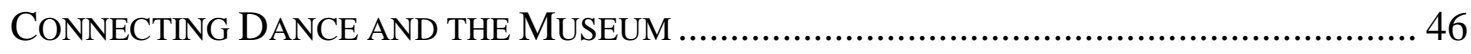

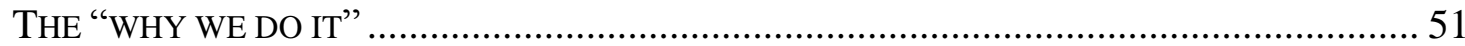

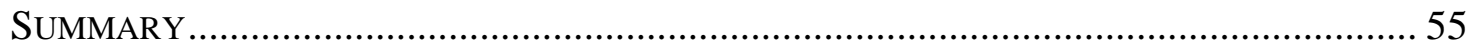

CHAPTER FIVE: CONCLUSIONS......................................................................... 57

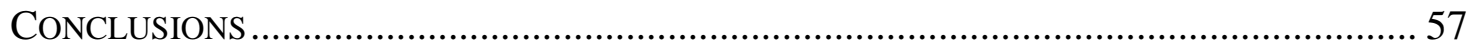

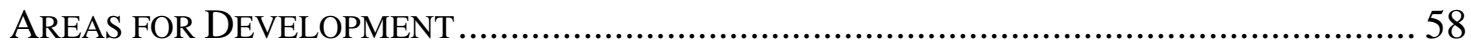

BIBLIOGRAPHY ......................................................................................................... 63

APPENDICES .......................................................................................................... 69

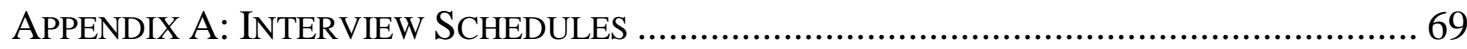

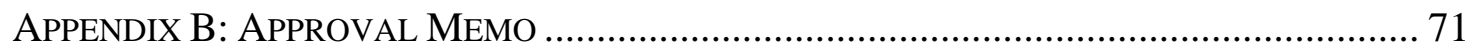

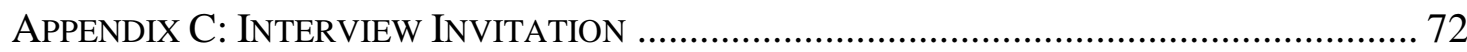

APPENDIX D: CONSENT FORM ………………………………………………..... 74

APPENDIX E: EXCERPT FROM MUSEUM OF WELLINGTON CITY AND SEA POLICY ............ 75

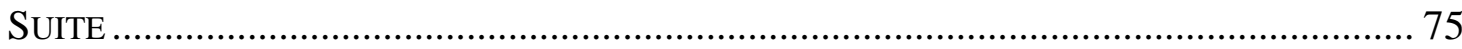

APPENDIX E: EXCERPT FROM WELLINGTON MUSEUMS TRUST STATEMENT OF INTENT 79 


\section{Chapter One: Introduction}

\section{Introduction}

In June 2010 the Museum of Wellington City and Sea offered a public programme called the Sampler Season. As part of this, I helped organise, and also participated in, an evening event called Real Hot Dance Moves, with the Wellington based dance troupe the Real Hot Bitches. ${ }^{1}$ The performance was a free evening event open to the public on a Friday night, and was aimed at men and women wanting a fun but also laid back experience after work. The aim of the event was for visitors to learn a dance routine, taught by the Real Hot Bitches, to the song "If You Could Read My Mind" by Viola Wills. Using a literary theme, the choreography tied in with the museum's current exhibition which was the location for the performance. The exhibition was called The Making of The Word Witch, and displayed the illustrating process and artworks from the Margaret Mahy book The Word Witch. The dance session had the highest visitor numbers of the Sampler Season for that year and was well received by visitors and other staff members who attended.

As a member of the dance troupe, as well as an employee of the museum, I was able to see the entire process. This included deciding which dance to do, the choreography process and the performance and teaching section of the night. This process highlighted that communication between the museum and the dance company was vital if the performance was to be a success. This ranged from arranging for the museum to allow the troupe to practice in the space after hours, through to ensuring that the dance troupe understood how much of the routine to teach. I also noticed the visitors' different reactions to the event and their reasons for coming. While the Real Hot Bitches had their own following, many visitors came to the event because it was a novelty and they were interested in trying something new. There were also many people who attended because they had come to expect high quality public events from the museum and they knew it would be worthwhile. This event provided the inspiration to investigate how dance can be incorporated in museums.

\footnotetext{
${ }^{1}$ The Real Hot Bitches are a Wellington based community dance troupe, open to people of any age or gender. Established in 2005, the group is a semi-professional comedy dance troupe who perform to music from the 1980's, with an emphasis on fun and equal opportunities for performers from a range of backgrounds. See www.real-hot-bitches.co.nz for more information.
} 
Dance has a place in museums as it can be classified as a form of intangible heritage. In New Zealand this is particularly important as dance can be a form of taonga. ${ }^{2}$

Defining dance as intangible heritage establishes that museums have an important role in preserving dance. A more in depth discussion of dance as a form of intangible heritage and a form of taonga is included in the Literature Review. There are also a number of different ways dance can be incorporated into the museum. As museum programmers attempt to appeal to a wide range of people, dance can be utilised to attract new visitors or provide new experiences for repeat visitors. Richard Kraus writes that dance "appeals to all social classes and widely ranging levels of artistic taste" allowing museums to pick and choose different dance events to suit their needs and the needs of their visitors. ${ }^{3}$ Ethnological dance in particular is used in museums to display the performing arts of indigenous cultures. In doing this, museums can display the music, clothing and dance performed by those cultures. In New Zealand this can be seen at The Museum of New Zealand Te Papa Tongarewa where Māori performance occurs on a regular basis, whether it is for an event or as part of a specific ceremony. ${ }^{4}$

Museums today also provide participatory experiences for their visitors. Dances such as ballet and modern dance require a high level of skill and experience, however social and recreational dance can provide opportunities for museum visitors to participate in dance as they require less skill and little prior knowledge. Social dance traditionally referred to ballroom dancing, Latin ballroom dancing and later to "rockand-roll or "discotheque" dances" in North America. ${ }^{5}$ This could now be expanded to include popular styles of social dancing such as swing dancing, ceroc and rock and roll dancing. Recreational dance, from a European perspective, included any traditional dance that was performed for recreation and not for ceremonial purposes. ${ }^{6}$ A wider definition of recreational dance includes dances usually performed in groups

\footnotetext{
${ }^{2}$ Property, treasure.

${ }^{3}$ Richard Kraus, History of the Dance in Art and Education, (Englewood Cliffs, New Jersey: PrenticeHall Inc., 1969), 8.

${ }^{4}$ Marilena Alivizatou, "Intangible Heritage and the Performance of Identity" in Performing Heritage: Research, Practice and Innovation in Museum Theatre and Live Interpretation, ed. Anthony Jackson and Jenny Kidd (Manchester: Manchester University Press, 2011), 89-90.

${ }^{5}$ Kraus, History of the Dance, 3.

${ }^{6}$ Teresa Buckland, "Traditional Dance: English ceremonial and social forms" in Dance History: An Introduction, ed. Janet Ashead-Lansdale and June Layson, (London: Routledge, 2004), 45.
} 
or social clubs, such as folk dancing and square or round dancing ${ }^{7}$. This definition can be further expanded and modernised, now including street dance such as hip-hop, krumping and popping and locking, where participants form groups or crews which dance together socially. Taking this into account, social and recreational dance can be used in museums if they are looking to provide a participatory experience for their visitors.

In order to make this research successful it needed to be focused. I decided to narrow down my research to only one type of dance. This was necessary as the scope for the dissertation needed to be relatively small. I decided to exclude performance art and ethnological dance from the research. Performance art was excluded as this is not dance in the strictest sense. Although it can utilise dance, performance art is a form in its own right. Ethnological dance was excluded as it has its own history and specific uses within museums, which are different to dance used in the context of this research. ${ }^{8}$ In order to carry out an in depth investigation, I chose to focus on Western theatrical dance, using a case study where contemporary dance was used in the museum. ${ }^{9}$ Western theatrical dance includes classical ballet, contemporary dance and variations of the two.

The following section, the Literature Review, first provides examples where dance has been used in museums. It establishes that dance has a place in museums as a form of intangible heritage and can be interpreted by visitors. Following this, it explores ways in which museums can incorporate dance in their exhibitions and public programmes. The section then concludes by examining the impact of dance on the museum visitor experience.

\section{Literature Review}

The first part of the literature reviews provides the context for this research through discussing examples of dance being used in museums. Firstly examples of dance being used to display ethnic performances and as a form of interpretation are

\footnotetext{
${ }^{7}$ Kraus, History of the Dance, 4.

${ }^{8}$ Māori dance in New Zealand will be discussed in the literature review however as it plays an important role in New Zealand museums.

${ }^{9}$ Ann Dils and Ann Cooper Albright, moving history / dancing cultures: A Dancer History Reader, (Middletown, Connecticut: Wesleyan University Press, 2001), 370.
} 
discussed. I have also included examples of museums specifically about dance, which are often part of dance schools. Following this the ways dance can be used in museums today is discussed. This literature includes the use of dance as a method of displaying intangible heritage and as a method of interpretation. Finally, the literature review covers theoretical reasons why dance should be used in museums. Here, the impact of dance on the museum visitor is also explored, including the meaning making experiences in the museum.

The performing arts have been utilised in museums for a considerable time. Edward P. Alexander writes that "often these activities were more or less independent of the museum collections, exhibits and programs, but sometimes they were employed as interpretive devices. ${ }^{10}$ Here, Alexander highlights the many functions dance has filled within a museum setting historically, from being an event (independent of the collections) through to being utilised as a form of interpretation or to enhance the museum collections. Despite the evidence that dance has been used in museums there is a lack of corresponding literature, both in the field of dance research and the field of museum studies.

Much of what has been written regarding the performing arts in museums focuses on live interpretation at heritage sites or in museums. The book "Performing Heritage", edited by Anthony Jackson and Jenny Kidd, focuses on museum theatre and live interpretation in museums and heritage sights. They use the term 'performance' rather than 'museum theatre' because it encompasses all aspects of performance, including first person interpretation as well as theatre. ${ }^{11}$ First person interpretation refers to instances where an actor plays a character, who interprets an objects or story. This is different to museum theatre, where a play or performance is staged as a method of interpretation. While this is not dance in the strictest sense (though they do provide an example of dance) they discuss the use of the performing arts in museums at length. A specific example of dance performed at a heritage site is included in Jackson and Kidd's book. Royona Mitra discusses the performance Weaving Paths, by the Sonia Sabri Dance Company, which was held at Bantock House, Wolverhampton, in the

\footnotetext{
${ }^{10}$ Edward P. Alexander, Museums In Motion, (California: Sage, 1996), 217.

${ }^{11}$ Anthony Jackson and Jenny Kidd, ed. Performing Heritage: Research, Practice and Innovation in Museum Theatre and Live Interpretation, (Manchester: Manchester University Press, 2011), 1.
} 
United Kingdom in 2007. ${ }^{12}$ In this example, the Sonia Sabri Dance Company took up a three week residency at the historic site, Bantock House. The aim was to create works on site in response to areas within the house. During this time, the house was open to the public, allowing visitors to experience the development of the pieces as a work in progress. ${ }^{13}$ In this example the dance is being created as a site-specific work (it was conceptualised, choreographed and performed on-site at Bantock House), with inspiration from the physical environment of the site as well as its history. The performances focused on "the interaction between the different cultural layers that characterise Wolverhampton's past and present". ${ }^{14}$ This differs from museum theatre, which typically focuses on an account of history or a story.

Jackson and Kidd also include the use of dance as a way to display intangible heritage in a chapter by Marilena Alivizatou. The chapter provides examples of dance being used in museums in her discussion of intangible heritage and identity. ${ }^{15}$ Alivizatou uses the example of traditional Māori performance at the Museum of New Zealand Te Papa Tongarewa (hereafter referred to as Te Papa). These performances were usually held on the marae $^{16}$ at Te Papa (Rongomaraeroa ${ }^{17}$ ). The events team identified that the kapa haka ${ }^{18}$ performances are the most popular at the museum. However, they also give examples of haka ${ }^{19}$, poi $^{20}$ dances and hip-hop performed by Māori and Pacific groups during the Matariki ${ }^{21}$ festival in 2007. The inclusion of theatre spaces in Te Papa also highlights that the need for a performance space was recognised from the early stages of building, indicating that the presence of the performing arts was envisaged from the outset.

Dance has also been used at the Musée du Quai Branly in Paris in many forms, including a show held in 2008 of Korean hip-hop performed to traditional Western

\footnotetext{
${ }^{12}$ Royona Mitra, "Performing Cultural Heritage in Weaving Paths by Sonia Sabri Dance Company" in Performing Heritage: Research, Practice and Innovation in Museum Theatre and Live Interpretation. ed Anthony Jackson and Jenny Kidd, (Manchester: Manchester University Press, 2011), 144.

${ }^{13}$ Ibid., 147-148.

${ }^{14}$ Ibid., 145.

${ }^{15}$ Alivizatou, "Intangible heritage and the Performance of Identity", 89-90.

${ }^{16}$ Meeting area, point of settlement, central area of village and its buildings.

${ }^{17}$ The name of the marae.

${ }^{18}$ Group or team performance of Maori dance. War dance.

${ }^{19}$ A fierce, rhythmical dance.

${ }^{20}$ A soft ball on a string, swung as part of a dance.

${ }^{21}$ Maori new year.
} 
music played on the zither, a traditional Korean string instrument. ${ }^{22}$ The director of the museum states that the Musée du Quai Branly was "not so much interested in a historic heritage that is about to disappear, but rather in the transformation and reappropriation of tradition". ${ }^{23}$ The examples from Te Papa and the Musée du Quai Branly illustrate ways in which museums can incorporate dance into their public programmes.

There are also instances mentioned elsewhere, where dance has been used to interpret objects in museums. Dwight Blocker Bowers discusses the performance of the musical Beggars Holiday at the Smithsonian in his chapter "And Now for Something Completely Different", featured in Exhibiting Dilemmas: Issues of Representation at the Smithsonian. ${ }^{24}$ In 1990 Bowers reconstructed the 1946 musical Beggars Holiday from the museum's collection of musical manuscripts, with a live performance being held. The intention was to display the objects (the musical manuscripts) in the way they had been originally intended to be used. This is a unique situation where dance has been used in a museum for interpretation. Similarly, the Museum of Bath at Work, in the United Kingdom, held an evening contemporary dance event called Machine. ${ }^{25}$ The piece was inspired by machinery found in the museum and was performed in the museum exhibition space. Devised and performed by first year students at the Trinity Laban Conservatoire of Music and Dance in London, the dancers researched the machinery found in the museum to inspire their movements.

There are also museums dedicated to dance history, for example the National Museum of Dance in Saratoga, California dedicated solely to dance history in the United States of America. ${ }^{26}$ Established in 1986 it has both permanent and temporary exhibitions, and recognises dancers, choreographers, teachers, designers, critics and patrons of dance. An extension of the museum is their School of the Arts, which is a

\footnotetext{
${ }^{22}$ Alivizatou, "Intangible heritage and the Performance of Identity", 88.

${ }^{23}$ Ibid.

${ }^{24}$ Dwight Blocker Bowers, "And Now for Something Completely Different: Reconstructing Duke Ellington's Beggar's Holiday for Presentation in a Museum Setting" in Exhibiting Dilemmas: Issues of Representation at the Smithsonian, ed. Amy Henderson and Adrienne L. Kaeppler, (USA: Smithsonian Institution, 1997).

25 "Guest Post: Sally Lewis on Music, Movement and Machinery at the Museum of Bath at Work" accessed17/6/2011, http://museumsatnight.wordpress.com/2011/04/05/guest-post-sally-lewis-onmusic-movement-and-machinery-at-the-museum-of-bath-at-work/ .

26 "National Museum of Dance" accessed 15/5/2011, http://www.dancemuseum.org/index.html
} 
not for profit organisation that teaches dance technique to a professional standard. Some dance schools have museums as part of their facilities, for example the Royal Ballet School in England, which has established the White Lodge Museum and Resource Centre. ${ }^{27}$ The museum includes exhibitions on the daily life of students at The Royal Ballet School, the history of ballet, including objects from the Royal Ballet School's collections. Both the National Museum of Dance in California and the White Lodge Museum offer events and shows which are open to the general public.

Dance literature in general focuses on the history and technique of dance rather than the sites where dance can be performed. There is also little written about how the audience perceives and interprets dance. Dance reviews are written by professional critics who generally have experience as a dancer or choreographer, rather than by a less experienced audience member. Kraus writes extensively on the history and development of Western dance, tracking the development of classical ballet and modern dance throughout the United States of America, including information about social and recreational dance. ${ }^{28}$

While this literature provides some examples where dance has been performed in museums, it does not sufficiently cover why dance should be used in museums or the roles it can play in the museum setting. The technical and practical aspects of dance in the museum are also left unmentioned, providing no way to know how the institutions worked with the dance companies on a practical level. The following section of the literature review will further explore the ways in which dance can be incorporated into museums, and the benefits of doing this. Firstly, literature discussing dance as a form of intangible heritage will be examined. This establishes the role dance has within a museum as an object or piece of heritage which can be displayed and interpreted. The New Zealand context is discussed by looking at the issues surrounding dance as a form of taonga. Dance literature focuses on interpretation made by critics and dance professionals, however there has been some recent investigation into interpretations made by audience members. This is significant because dance events at museums will attract a range of different people, not only dance professionals.

\footnotetext{
${ }^{27}$ http://www.royal-ballet-school.org.uk/wl_museum.php?s=1 .

${ }^{28}$ Kraus, History of the Dance.
} 
Secondly, the impact of dance on the visitor experience is explored. This is an important area for investigation as museums must pay more attention to the experiences they provide today. This section first discusses the characteristics of the modern museum visitor. Following this the section highlights how many museum visits are now social experiences and looks into the ways in which dance can be used in this context. Dance can also play an important role in museum marketing. It can be used to draw in new visitors and expand the market for potential museum visitors. This is an important consideration for modern museums as they are now part of the wider leisure market and must compete for visitation. Though museums do have a place in today's leisure market, they are still perceived as being educational, though they are considered to be informal learning environments, where visitors can learn something but still enjoy themselves.

Thirdly, dance as a form of interpretation is investigated, including how this impacts on visitor meaning making and overall visitor experience. Museums today are using a multitude of interpretation methods, including using narrative interpretation. Dance can function as a narrative form and therefore be used as an interpretation tool for storytelling. The interpretation of objects and stories within the museum will influence the meaning making process of the visitors; therefore I have investigated the way dance could impact upon this process.

\section{Dance as Intangible Heritage}

Dance can be defined as a form of intangible heritage which gives it an important place in museums. Intangible heritage is defined by William Logan as "heritage that is embodied in people rather than in inanimate objects". ${ }^{29}$ Using this definition, dance can be classed as intangible heritage because the act of dancing is embodied only in people. While dance can be recorded, and there are tangible objects associated with dance, the performance itself can only be done once. Dance is traditionally taught by passing on knowledge from person to person through teaching. This means that every performance of a dance will be different, as each person teaches in a different style or

\footnotetext{
${ }^{29}$ D.F Ruggles and H. Silverman, "From Tangible to Intangible Heritage" in Intangible Heritage Embodied ed. D.F Ruggles and H. Silverman, (New York, Springer, 2009), 1.
} 
has a different interpretation of the choreography. Dance notation attempts to translate dance into written signs. ${ }^{30}$ These systems of notation are limited. Firstly, errors can be made in the description of movement, the recording of the notations and the level of detail used. ${ }^{31}$ Also, unlike music notation, there are a number of systems, developed and used by different people throughout history from the eighteenth century onward. ${ }^{32}$ This means there is not yet a universal language of dance notation. Again, this makes it difficult to reliably record and pass on dance movement in this manner. These factors contribute to the difficulty in passing on dance techniques in ways other than through teaching and the ephemeral nature of dance is what makes it unique in comparison to the other arts. ${ }^{33}$ The United Nations Educational, Scientific and Cultural Organisation (UNESCO) recognise the importance of dance as intangible heritage and as a result the performing arts are listed as intangible heritage in the Convention for the Safeguarding of the Intangible Cultural Heritage 2003. ${ }^{34}$ D.F Ruggles and H. Silverman reference this as the point where dance took its place alongside tangible objects as "a legitimate characteristic of some kinds of historic structures". ${ }^{35}$ In relation to museums, if dance can be a form of intangible heritage then museums have a responsibility to preserve and protect dance where appropriate.

Recognising dance as a form of intangible heritage is particularly relevant in the New Zealand context as taonga extends to dance and other forms of intangible heritage. A simple definition of taonga is that it is a physical treasure. However a deeper understanding reveals that dance can be taonga. Paul Tapsell (referencing Kawharu) provides an extended definition of taonga, that "'taonga' refers to all dimensions of a tribal group's estate, material and non-material - heirlooms and wahi tapu, ancestral lore and whakapapa etc." ${ }^{36}$ Because taonga includes the non-material, dance then can be defined as taonga and therefore should be protected and preserved as a form of intangible Māori heritage. Hirini Moko Mead lists “war dance, poi dances, traditional

\footnotetext{
${ }^{30}$ Ann Hutchinson Guest, Dance Notation: The Process of Recording Movement on Paper, (New York: Dance Horizons, 1984), xiv.

${ }^{31}$ Ibid., 117-119.

32 Ibid., 62-115.

${ }^{33}$ Kraus, History of the Dance, 6.

34 "Convention for the Safeguarding of the Intangible Cultural Heritage" accessed 19/5/2011, http://unesdoc.unesco.org/images/0013/001325/132540e.pdf .

${ }^{35}$ Ruggles, "From Tangible to Intangible Heritage", 6.

${ }^{36}$ Paul Tapsell, "The Flight of Pareraututu: An Investigation of Taonga from a Tribal Perspective" The Journal of the Polynesian Society 106, no. 4 (1997):326.
} 
waiata and action songs" as traditional Māori dance, all of which are still performed today. ${ }^{37}$ Moko Mead recognises that Māori are "still performing the same dances", yet he notes that the style and music has become more modern over time. ${ }^{38}$ The performance of dance can also result in emotional reactions, as Tapsell writes that "for Māori, if an item, object or thing is described as he taonga it immediately elicits a strong emotional response". ${ }^{39}$ Tapsell writes that taonga can exert ihi, wehi and wana on an audience. Ihi refers to spiritual power, spontaneous physical reaction to something and being able to feel an awesome presence. Wehi refers to the feeling of the hairs standing up on the back of your neck, or making your spine tingle. Wana is the unquestioned authority and integrity of the performance. These are the physical and emotional reactions an audience can have when taonga is performed. Tapsell also notes that this is not limited to ritual performances. It is not uncommon to hear someone describe a live performance as being spine tingling, or sending shivers up their spine. The Māori terms ihi, wehi and wana capture these feelings, but they are felt by many different people while watching many types of dance.

Serious study into the cognitive processes involved when watching dance also reveal the different physical and emotional reactions people have when watching dance. Catherine Stevens writes that people will follow a beat or rhythm and adapt their breathing according to what they observe. ${ }^{40}$ In addition, Renee Glass identifies what causes emotional reactions in audience members watching dance performances. She writes that participants responded emotionally to various aspects of dance, with aural elements eliciting an emotional response in $43.4 \%$ of observer's. ${ }^{41}$ Other elements which provoked emotion are the characteristics of the dancer, their physicality, visual elements of the performance, images and the spatial elements of the performance. ${ }^{42}$

\footnotetext{
${ }^{37}$ Hirini Moko Mead, Tikanga Maori: Living by Maori Values. (Wellington: Huia Publishers, 2003), 253.

38 Ibid.

${ }^{39}$ Tapsell, "The Flight of Pareraututu: An Investigation of Taonga from a Tribal Perspective", 326.

${ }^{40}$ Catherine Stevens, "Trans-disciplinary Approaches to Research into Creation, Performance and Appreciation of Contemporary Dance" in Thinking in Four Dimensions. eds Robin Grove, Catherine Stevens and Shirley McKechnie (Melbourne: Melbourne University Press, 2005),161.

${ }^{41}$ Renee Glass, "Observer Response to Contemporary Dance" in Thinking in Four Dimensions. eds Robin

Grove, Catherine Stevens and Shirley McKechnie, (Melbourne:Melbourne University Press, 2005),118.

${ }^{42}$ Ibid., 118.
} 
Dance can also take on the role of an object in the museum. Graham McFee writes that dance can be viewed as a "fit object for understanding" like any other work of art. ${ }^{43} \mathrm{McFee}$ bases this on the fact that dance is expressive, and finding a dance expressive means we are involved in interpreting it, or making sense of it. ${ }^{44}$ As such, in the action of trying to understand a dance we deem the dance as an object fit for understanding and interpreting. McFee then states that "dances are essentially interpreted objects". ${ }^{45}$ The people who watch the dance are interpreting it. While McFee establishes that dances are objects worthy of interpretation, he also writes that this interpretation is "done through what I am calling criticism" and that this is best done by "established critics". ${ }^{46}$ This excludes the audience members who are not professionals in the dance world, focusing only on those with a background in dance as being able to interpret dance. This is typical of dance literature, where critics and dance professionals write on the interpretations or meanings of dance without acknowledging any audience involvement. Conversely, Renee Glass identifies that "most observers actively interpret contemporary dance" in her investigation of the cognitive processes involved in watching dance. ${ }^{47}$ The observers in Glass's study are audience members, not dance professionals indicating that non-dance professionals also make interpretations of dance when watching it.

\section{The museum visitor and their experience}

Visitors to museums can interact with dance in a number of ways. These interactions can enhance their experience and in turn, benefit the museum. Historically, the public museum came into existence in the late eighteenth and early nineteenth centuries with the idea that high-culture was a "resource that might be used to regulate the field of social behaviour". ${ }^{48}$ Nineteenth century reformers in particular saw high-culture institutions as antidotes to social ills and as a way to civilise the population. ${ }^{49} \mathrm{As}$ a result, museums became a place for the public, as opposed to being restricted to certain members of high society. ${ }^{50}$ Museums during this time were also concerned with collecting and classifying, in science, anthropology and other disciplines. Tony

\footnotetext{
${ }^{43}$ Graham McFee, Understanding Dance, (London: Routledge, 1992), 152.

${ }^{44}$ Ibid., 151.

${ }^{45}$ Ibid., 154 .

${ }^{46}$ Ibid., 154.

${ }^{47}$ Glass, "Observer Response to Contemporary Dance ", 115.

${ }^{48}$ Tony Bennett, The Birth of the Museum: history, theory, politics, (London:Routledge, 1995), 20.

${ }^{49}$ Ibid., 22.

${ }^{50}$ Ibid., 24.
} 
Bennett identifies that museums were born at the same time as "a new set of knowledges... each of which, in its museological deployment, arranged objects as parts of evolutionary sequences". ${ }^{51}$ Graham Black identifies that unfortunately, this archetype of a museum has still excluded many people in society. ${ }^{52}$ While museums in the twenty first century remain open to the public, the image of what a museum is and what it is for has significantly changed over time. Visitors now expect a different experience from their museum visit.

\section{The community impact of dance in museums}

Neil Kotler writes that museums are increasingly being seen as "parts of a cultural mosaic" which team up with other cultural organisations in their communities. ${ }^{53}$ Dance provides an avenue for museums to achieve this. Fiona McLean writes that "museums are seen as ideal venues for entering into direct partnership with local arts organisations, providing venues and back-up activity for local arts activity." has a long standing place in communities as a recreational and social activity. ${ }^{55}$ These communities can range from ethnic groups performing their traditional dance through to people who form a community around dance as their common interest. ${ }^{56} \mathrm{By}$ incorporating local or community dance groups into their programming, museums can become a more integrated part of the cultural mosaic Kotler refers to. These partnerships can also lead to the removal of barriers which prevent people from visiting the museum, particularly those who may feel disenfranchised by the concept of a traditional museum. McLean writes that "the fundamental barrier to access in museums is psychological access, where certain sectors of the population or a number of the public feel disenfranchised, because of a sense of alienation from the dominating societal discourse of the museum" and as such, many people may feel excluded from museums. ${ }^{57}$ The Social Exclusion Unit of the New Labour government in the United Kingdom in 1997 provides a useful definition of social exclusion risk factors, cited by Black. These are as follows:

\footnotetext{
${ }^{51}$ Ibid., 96.

${ }^{52}$ Graham Black, The Engaging Museum: Developing museums for visitor development (New York: Routldge, 2005), 50.

${ }^{53}$ N. Kotler,"New ways of Experiencing Culture" the Role of Museums and Marketing Implications." Museum Management and Curatorship 19,4,(2001):418.

${ }^{54}$ Fiona McLean, Marketing the Museum, (London: Routledge, 1997), 79.

${ }^{55}$ Kraus, History of the Dance, 340.

${ }^{56}$ Kraus, History of the Dance, 341.

${ }^{57}$ McLean, Marketing the Museum,75.
} 
low income; family conflict; being in care; school problems; being an exprisoner; being from an ethnic minority; living in a deprived neighbourhood in urban and rural areas; mental health problems; age and disability. ${ }^{58}$

Black writes that because this unit was high-profile, museums have had to respond proactively as they are often criticised for catering "only for a privileged, affluent minority in society. ${ }^{, 59}$ As a result, museums have had to work towards becoming more inclusive, broadening their audience to include those who may previously have been excluded. Because dance encompasses so many facets of culture, those who may feel disenfranchised from the museum can feel included, as in incorporating social and recreational dance, museums can also blur the lines between what N. Kotler refers to as popular (informal) and elite (formal) culture in an experience. This again would remove barriers for those who feel they are not able to visit museums. Dance can span from high-culture (ballet, modern dance) to low-culture (social and recreational dance) and therefore appeal to a wide range of people. This could possibly provide avenues for participation by those who feel excluded from the museum.

\section{Social groups and the museum}

John Falk and Lynn Dierking state that "most people visit the museum in a group, and those who visit alone invariably come into contact with other visitors and museum staff" making museum visits inherently social experiences. ${ }^{60}$ Here, a group refers to two or more people attending the museum together for social purposes. By expanding on Rosenfeld's (1980) ideas Falk and Dierking also identify that a significant amount of time in the museum is spent on social interaction. ${ }^{61}$ Museum visitors are also seeking a more social visitor experience. ${ }^{62}$ This trend in visitor behaviour has lead to museums attempting to provide a sociable, recreational and participatory experience. ${ }^{63}$ Museums can do this by removing barriers which prevent social interaction, for example by creating exhibitions which encourage visitor conversation. ${ }^{64}$ Kotler references a variety of different institutions who have been

\footnotetext{
${ }^{58}$ Black, The Engaging Museums, 49.

${ }^{59}$ Ibid., 50.

${ }^{60}$ John H. Falk and Lynn D. Dierking, The Museum Experience, (Washington: Whalesback Books, 1994), 3.

${ }^{61}$ Falk, The Museum Experience, 41.

${ }^{62}$ Kotler, ""New ways of Experiencing Culture", 418.

${ }^{63}$ Ibid., 418.

${ }^{64}$ Falk, The Museum Experience, 143.
} 
successfully creating "events to satisfy sociable needs". ${ }^{65}$ This illustrates the way museums can provide social experiences through public programmes. These events can be an opportunity for museums to incorporate dance. Dance can provide social activities for museum visitors to participate in. Recreational and social dance are the simplest ways people can participate in dance, as these dances are designed to be performed by everyday people and in groups. ${ }^{66}$ Recreational dance particularly allows for amateur involvement. Line dancing for example involves simple repetitive steps which are easy to learn and are not physically demanding. In a museum setting this could be facilitated through a public programme or event where visitors are invited to participate in a dance activity or lesson. These sorts of programmes could also include more formal types of dance, for example ballet, tap or modern dance. In these situations an expert could come into the museum and teach visitors a range of steps and techniques.

Family groups are another distinct social grouping of museum visitors. ${ }^{67}$ Eilean Hooper-Greenhill notes that families are no longer the typical nuclear family, but can be "a group of adults and children where a range of relationships may be represented". ${ }^{68}$ Families have different needs within the museum to other types of social groups, such as availability of food and drink, accessibility for prams, car parking, and exhibitions suitable for children. Both Hooper-Greenhill ${ }^{69}$ and Falk and Dierking ${ }^{70}$ identify that families seek a social environment which provides shared activities and opportunities for questions and discussion between group members. Hooper-Greenhill also identifies that children need "opportunity for physical expression" and dance can be one way to provide this. ${ }^{71}$ Because dance can appeal to both adults and children alike it can provide a social and physical experience for a family group.

\footnotetext{
${ }^{65}$ Kotler, ""New ways of Experiencing Culture", 421.

${ }^{66}$ Kraus, History of the Dance, 3-4.

${ }^{67}$ Eilean Hooper-Greenhill, Museums and their Visitors, (London: Routledge, 1994), 101.

${ }^{68}$ Ibid., 102.

${ }^{69}$ Ibid., 103.

${ }^{70}$ John H. Falk and Lynn D. Dierking, The Museum Experience, (Washington: Whalesback Books, 1994), 45.

${ }^{71}$ Hooper-Greenhill, Museums and their Visitors, 103.
} 
The modern museum is now part of the wider leisure market where visitors consume the museum as part of a leisure experience, rather than simply visiting the museum for an educational experience. ${ }^{72}$ As a result, visitor behaviour has changed as people want different things from their museum visit. This change in behaviour has led to significant implications for museum marketing as institutions must now compete with other leisure providers to attract visitors. Chris Bruce writes that "the thrust of today's museums is to attain status, to be a destination, and to appeal to a mass audience" as they compete for people's custom in today's leisure market. ${ }^{73}$

Consumer trends in the 1990s indicate that people are seeking adventurous experiences in their leisure time. The term "Fantasy Adventure" refers to the desire to have exciting exploits, heartfelt experiences, exotic adventures, and broad sensory and emotional experiences, but to undertake them in the safest possible ways. ${ }^{74}$ Joanne Scheff and Phillip Kotler recommend this for the performing arts as they can offer visitors a safe 'adventure by association' and 'fantastic experiences from the comfort of their theatre seat" ${ }^{75}$ Using dance gives museums the opportunity to offer this riskfree adventure and dance can be the exotic or the unusual experience. This could occur in a number of ways. Visitors could learn traditional dances from different cultures, for example belly dancing and different types of folk dancing, or visitors could attend a show and watch a performance they may not have seen before. The museum can be the safe place where people go to participate in this unusual experience. This is supported by evidence from the Charter for the Arts in Scotland, 1993, which finds that museums have a "positive image" and are seen as "being popular, democratic and accessible" thus indicating that people do in fact see museums as a safe place to go. ${ }^{76}$ The Charter also states that "this offers museums the opportunity to help break down the cultural barriers for other art forms, since they are ideal venues for activities related to the arts and culture" demonstrating that incorporating dance in museums is marketable to the public. ${ }^{77}$ Thus, dance can be

\footnotetext{
${ }^{72}$ M Foley and G. McPherson, "Museums as Leisure" International Journal of Heritage Studies, 6, 2, (2000), 161.

${ }^{73}$ Chris Bruce, "Spectacle and Democracy: Experience Music Project as a Post-Museum" in New Museum Theory and Practice: An Introduction, ed. J Marstine, ( UK:Blackwell, 2006), 130.

${ }^{74}$ Joanne Scheff and Phillip Kotler, Standing Room Only: Strategies for Marketing the Performing Arts ,(Boston: Harvard Business School Press, 1997), 70.

${ }^{75}$ Ibid.

${ }^{76}$ McLean, Marketing the Museum, 79.

${ }^{77}$ Ibid., 79.
} 
used to appeal to the fantasy-adventure seekers by providing a unique experience in a safe environment.

Falk and Dierking write that museums are "tried-and-true sources of understandable information" and museum visitors do still view museums as providing an educational experience. ${ }^{78}$ Museums must find a balance in satisfying people's desire for an entertaining and social visit as well as an educational visit. This is somewhat aided by museums being viewed as "informal learning settings", where people will learn through experiences rather than being taught as they would at school. ${ }^{79}$ Falk and Dierking categorise this as "free choice learning" because visitors choose to attend the museum and choose what they look at when they are there, differentiating museums from other learning environments. ${ }^{80}$ Bruce states that "museums have had to adjust, and are now in the "experience" business" and as a result, they are challenged to create new and dynamic displays in order to attract new visitors. This combination of education and entertainment has led to the portmanteau term 'edutainment' ${ }^{81}$ Leonie Lockstone, referencing Kotler and Kotler, states that 'edutainment' "represents presentation styles and designs that fulfill the dual goals of entertaining and educating the visitor." 82 Many people would see this as a negative. However Bruce writes that "just as the first rule of teaching is to get the pupil's attention, it is this focus on the proactive engagement of the visitor that defines the post-museum. ${ }^{83}$ McLean $^{84}$ and Hooper-Greenhill ${ }^{85}$ both expound the virtue of using entertainment as education in the museum, because they recognise that people are more likely to learn if they are enjoying themselves. Dance can be used as a form of 'edutainment' in a museum setting. The example mentioned previously, where Korean hip-hop was performed at the Musée du Quai Branly, combined dance found in popular entertainment (hip-hop) with traditional music, thus providing an opportunity to be entertained but also learn

\footnotetext{
${ }^{78}$ John. H. Falk, Lynn. D. Dierking, Learning from Museums, (California: Altamira Press 2000), 2.

${ }^{79}$ Falk, The Museum Experience, 99.

${ }^{80}$ Falk, Learning from Museums, 13.

${ }^{81}$ Bruce, "Spectacle and Democracy: Experience Music Project as a Post-Museum", 131.

${ }^{82}$ Leonie Lockstone "Maor Case Study" Shape shifters - the role and function of modern museums" in Museum Marketing: Competing in the Global Marketplace, ed Ruth Rentschler and Anne Marie Hede, (Oxford:Elsevier Ltd.,2007), 62.

${ }^{83}$ Bruce. "Spectacle and Democracy: Experience Music Project as a Post-Museum", 131.

${ }^{84}$ McLean, Marketing the Museum, 27.

${ }^{85}$ Hooper-Greenhill, Museums and their Visitors, 140.
} 
about Korean culture. This would be particularly attractive to teenagers, consumers of hip-hop culture.

Furthermore, dance has also had a longstanding relationship with education. Dance has been taught in different societies, from Margaret Mead's observations of dance in Samoan village life, through to social dance in Western society. ${ }^{86}$ From the Renaissance onward social dance (what we would now call court dancing or ballroom dancing) was taught as a part of everyday life.$^{87}$ Educational writings from the seventeenth and eighteenth centuries included dance for its perceived benefits to hygiene, health and exercise. ${ }^{88}$ In the twenty first century, dance is commonly utilised in education through physical education and arts education. In New Zealand, dance is part of the New Zealand curriculum (written in 2010) for schools (not dance or ballet schools, but state or private education), and is cited as promoting "personal and social well-being by developing students' self-esteem, social interactions, and confidence in physical expression. ${ }^{\prime 89}$ Participating in dance also gives visitors opportunity for self expression. Contemporary dance in particular is seen as an artistic expression of the performer. ${ }^{90}$ If dancers can express themselves through dance, then museum visitors participating in dance are also able to.

\section{Dance as a form of interpretation}

As discussed above, dance can be a form of intangible heritage which can be interpreted by a museum visitor. However, dance also functions as a narrative form used to interpret objects and stories within the museum. The following will examine the use of dance as a form of interpretation in the museum context. Hooper-Greenhill writes that "'object interpretation' is the attempt to interpret objects for others, by making links between the object and the viewer that they might be expected to recognize". ${ }^{91}$ As museums change and move into the twenty first century there are increasing changes to the way they convey information. Current trends in museum practice have shifted toward the use of new and innovative methods of interpretation

\footnotetext{
${ }^{86}$ Kraus, History of the Dance, 119.

${ }^{87}$ Kraus, History of the Dance, 121.

${ }^{88}$ Ibid., 122.

89 "Dance in the New Zealand Curriculum", accessed 1/6/2011, http://www.tki.org.nz/r/arts/curriculum/statement/dance_curric_e.php.

${ }^{90}$ Kraus, History of the Dance, 2.

${ }^{91}$ Eileen Hooper-Greenhill "Education, communication and interpretation" in The Educational Role of the Museum, $2^{\text {nd }}$ Edition (Routledge, London, 1999), 12.
} 
and as a result museum displays are becoming narrative based as opposed to object based. This narrative technique is discussed by Hooper-Greenhill, as she states "ideas are now more important than objects. Now the idea is to tell a specific story, and objects are gathered as they relate to the story." 92 The shift from object based to narrative based exhibitions provides a context which allows dance to be incorporated into museum exhibitions. Though museums still use objects, exhibitions have shifted away from being simply object based, to using objects to tell a story. Objects alone are no longer the most important part of an exhibition. This theory is emphasised by Elaine Heumann Gurian in her questioning of the importance of objects in museums. Gurian emphasises the importance of the role objects play in the narrative stories museums are trying to tell, as opposed to the objects being important as stand-alone pieces. ${ }^{93}$ Gurian and Hooper-Greenhill both highlight the shift towards narrative and storytelling in museums and away from object based exhibitions.

Monika Fludernik provides a simple but effective definition of narrative, stating that "narrative is associated above all with the act of narration and is to be found wherever someone tells us about something." 94 Narrative then, is the way in which stories are told and are the way in which people understand the world around them, process information, and conceptualise their knowledge and surroundings. Research shows that narratives are the building blocks of people's structured knowledge. ${ }^{95}$ People use narrative to keep the memory of a chain of events in the correct order and they use narratives to remember information they have learnt and to pass on information. The importance of narrative in culture is illustrated by the fact that ancient cultures sought their origins in myths and recorded them. ${ }^{96}$ This shows that forming narratives is a historic human activity. Narrative interpretation then, utilises basic human nature by passing on information through storytelling.

\footnotetext{
${ }^{92}$ Eilean Hooper-Greenhill, Museums and the Shaping of Knowledge, (London: Routledge, 1992), 206.

${ }^{93}$ Elaine Heumann Gurian, "What is the object of this exercise? A meandering exploration of the many meanings of objects in museums" Humanities Research, 8,1,(2001): 26, accessed 25/6/2011. url: http://proquest.umi.com/pqdweb?did=44467215\&sid=5\&Fmt=3\&clientId=7511\&RQT=309\&VName= PQD

${ }^{94}$ Monika Fludernik, An Introduction to Narratology ,(New York: Routledge, 2009), 1.

${ }^{95}$ Falk, Learning from Museums, 48-49.

${ }^{96}$ Fludernik, An Introduction to Narratology, 1.
} 
Dance is a form of narrative in its own right and as such can be used as a form of narrative interpretation. Recent developments in narrative theory have led to dance being defined as a form of narrative and a mode of communication. ${ }^{97}$ Dance has "Kinetic Properties" because it relies on "the human body as means of expression", qualifying it as a form of narrative. ${ }^{98}$ Narrative is most apparent in classical ballet, which evolved to become "a form of theatrical storytelling through dance" in the seventeenth century. ${ }^{99}$ Contemporary dance easily lends itself to being a form of interpretation. This is because it is seen more as a method of self-expression, or the expression of other things, rather than being bound by the rules and structure of classical ballet. ${ }^{100}$ Interestingly for museums, "a dance performance yields up multiple interpretations". ${ }^{101}$ The ambiguity of what a dance performance means or what story it is telling could be problematic as a viewer could interpret a completely different meaning to that intended by the museum. While the museum can never totally anticipate what meaning a visitor may take from any form of interpretation, dance remains a more unpredictable form of interpretation.

Considering dance as a form of interpretation also provides an authentic representation of certain objects in the museum setting. D.J Timothy and S. W Boyd write that "authenticity is associated with portraying the past in an accurate manner". ${ }^{102}$ They discuss authenticity in a heritage tourism context, stating that "people travel in search of authentic experiences and places". ${ }^{103}$ Referencing Bruner (1994) they establish that in heritage there is a four-part typology of authenticity. ${ }^{104}$ Summarising the typology, we first have authentic reproduction, where the site is given the overall appearance of being original and is believably original to the visitor. Secondly, the site not only appears to be in original condition but is a complete and accurate replica of its original state. Thirdly, the historic site is actually original, as opposed to being accurately copied from the original. This level of authenticity is difficult in heritage sites as buildings are often decayed. Lastly, the authenticity of the

\footnotetext{
${ }^{97}$ Eds. David Herman, Manfred Jahn and Marie-Laure Ryan, Routledge Encyclopedia of Narrative Theory, (New York: Routledge, 2005), 95-96.

${ }^{98}$ Ibid., 291.

${ }^{99}$ Kraus, History of the Dance, 71.

${ }^{100}$ Kraus, History of the Dance in Art, 137.

${ }^{101}$ Herman, Routledge Encyclopedia of Narrative Theory, 96.

${ }^{102}$ D.J Timothy and S.W Boyd, Heritage Tourism, (New York: Pearson Education, 2002), 237.

${ }^{103}$ Ibid., 238.

${ }^{104}$ Ibid., 238.
} 
site is authoritatively declared as being authentic. This again is problematic as it raises the question of who has the power or authority to authenticate the site. These four typologies can be seen as different levels of authenticity in historic sites.

Typologies of authenticity can be applied to dance as a form of interpretation. To do this, we consider the dance related objects to take the place of the heritage site. The act of dancing then becomes the interpretation of those objects. Dance related objects or archives could range from costuming and shoes, set related objects (backdrops, set pieces, props), or music related objects (musical scores, choreographic notes). The first level of authenticity would be that the dance related objects were replicated and then presented to the visitor to view. The second level would be where the entire setting and objects were replicated and used for their original purpose. Thirdly, we would see actual objects being used, rather than copies. This could potentially be problematic as irreversible damage could occur to the objects. The fourth level of authenticity, where the site is authoritatively recognised as authentic could also be problematic. In this situation, it would be up to dance historians and museum curators to determine whether or not the reproduction was authentic. The reproduction of the musical Beggars Holiday (discussed previously as an example of dance in museums) at the Smithsonian provides an example of live dance and performance in general being utilised to authentically interpret dance related objects. Bowers states that above all, these unique performances allow curators to display and interpret collections of musical manuscripts to their utmost, restoring them to the context for which they were originally created - to be interpreted through live performance. ${ }^{105}$

By producing a live musical performance, Bowers interpreted the objects (the manuscripts) as authentically as possible, by using them as they were originally intended. Also, a live production of Beggars Holiday provided a dynamic and unique interpretation of the manuscripts, as opposed to a static display. This theory could also be applied to the display of other dance related objects, such as costumes and sets.

\footnotetext{
${ }^{105}$ Blocker Bowers, “And Now for Something Completely Different: Reconstructing Duke Ellington's Beggar's Holiday for Presentation in a Museum Setting", 272.
} 
Dance also provides a multi-sensory form of interpretation. Cognitively, an observer of dance will experience visual, aural and kinesthetic stimulation. ${ }^{106}$ Choreographers can also utilise design elements such as staging, lighting and costuming to add to their work. This multi-sensory experience is one a visitor is not likely to forget, and as Stephanie Weaver suggests "visitors who have had a complete sensory experience remember it and tend to rate it highly". ${ }^{107}$ Expanding on this, Weaver discusses the use of surprises to entice visitors. Weaver uses the Disney term "Practical Magic" to describe the way a museum can give the visitor a (pleasant) surprise when they come to the museum. ${ }^{108}$ Kotler calls this the "wow" experience, an "out-of-the-ordinary, enchanting experience". ${ }^{109}$ By using an unusual method, the interpretation of an object can be the surprise that Weaver discusses. While museums can be known for hosting dance events, the use of dance in the day to day running of the museum could provide this surprise.

\section{Visitor Meaning Making}

The following section discusses visitor meaning making in a museum setting. HooperGreenhill states that "hermeneutics tells us that the construction of meaning depends on prior knowledge, and on beliefs and values." ${ }^{\prime 10}$ This means that a visitor's personal background and knowledge will influence the meaning making process during a museum visit. Falk and Dierking examine visitors' backgrounds in their study of visitor meaning making which they state is the root of all learning. ${ }^{111}$ Meaning making encompasses all aspects of the museum visit and the process of meaning making is innate in human beings. ${ }^{112}$ Falk and Dierking investigate visitor meaning making through their Contextual Model of Learning, which uses three personal contexts to examine the learning process. ${ }^{113}$ The first is the personal context of the visitor, who they are, their previous experience and their existing knowledge. ${ }^{114}$ The second is the social context, which is who they visit with and who they come into

\footnotetext{
${ }^{106}$ Glass, "Observer Response to Contemporary Dance", 108.

${ }^{107}$ Stephanie Weaver, Creating Great Visitor Experiences, (California: Left Coast Press, 2007), 104

${ }^{108}$ Ibid., 110.

${ }^{109}$ Kotler. (2001). "New ways of Experiencing Culture", 419-420.

${ }^{110}$ Hooper-Greenhill "Education, communication and interpretation", 13.

${ }^{111}$ Falk, Learning from Museums, 61.

${ }^{112}$ Ibid., 113

113 Ibid, 10.

${ }^{114}$ Falk, The Museum Experience, 2.
} 
contact with during their visit. ${ }^{115}$ Thirdly, Falk and Dierking discuss the physical context of the museum. ${ }^{116}$ These three contexts work individually, and intersect, to make up the visitor experience. This is supported by Hooper-Greenhill who also recognises that the visit is shaped by the museum experience as a whole. ${ }^{117}$ Using Falk and Dierking's three learning contexts we can examine the meaning making process involved where dance is incorporated in the museum. ${ }^{118}$

Visitor meaning making in the museum can occur in a number of ways. Firstly the personal context is considered. The visitor will use his or her existing knowledge and prior experience of both museums and dance to attempt to interpret the dance.

Secondly we have the social context. The visitor may consult the people they have attended the museum with, or ask museum staff members for assistance in interpreting the dance performance. They may also consult others to navigate the unusual setting of a museum hosting a dance performance, for example where would you buy tickets or where is the stage? Lastly the physical context can be examined. The physical environment of the museum will dictate where the performance is held and where the visitor observes the performances. The museum environment could also influence the way the dance is performed, depending on the size of the space and other factors. Ultimately, meaning is always relative to the individual so no visitor will take the same meaning from their museum visit. ${ }^{119}$ Therefore, while one can make an attempt to predict how a visitor will make meaning from dance in the museum there are no guarantees that the assumption will be correct.

Dance in the museum can also be a participatory experience, where visitors take part in a dance event. Falk and Dierking's three contexts still apply but in different ways. Social interaction occurs as the group talks to each other while participating in the experience. People may discuss what they are doing or ask questions about what to do next, or talk to the instructor. The physical context of the museum is also relevant. While the museum environment is not specifically designed for dance, it could potentially provide familiarity for the visitor if they regularly visit that place. The

\footnotetext{
${ }^{115}$ Falk, The Museum Experience, 3.

${ }^{116}$ Ibid., 3.

${ }^{117}$ Eileen Hooper-Greenhill "Communication in theory and practice" in The Educational Role of the Museum, $2^{\text {nd }}$ Edition,(London: Routledge, 1999), 4.1

${ }^{118}$ Falk, The Museum Experience, 2.

${ }^{119}$ Falk, Learning from Museums, 61.
} 
museum may also be more comfortable than a professional dance studio for the same reasons. The personal context, where prior experience is taken into account, is particularly relevant. In participating in a dance event at a museum, the visitor may be experiencing something totally new to them. Visitors might draw on prior knowledge of dance they have participated in, or watched, to assist in their experience.

In dance literature, the meaning taken from dance is discusses primarily from the viewpoint of the dance professional or the critic. $\mathrm{McFe}^{120}$, Myron Howard Nadel and Constance Gwen Nadel ${ }^{121}$ and Kraus ${ }^{122}$ focus solely on the dance critic as the interpreter of dance. Dance critics examine the dance from an outsider point of view, but with extensive prior knowledge. Therefore, critics are different to a less experienced audience member. Interestingly McFee argues that "as long as any critical interpretation of a particular dance is based on perceptible features of that dance, together with appropriate informed critical theory, it will be equally 'good"'. ${ }^{23}$ Here McFee does not rate one critic over another and one could assume that if an audience member made an interpretation of a dance which was informed both by the dance and by dance theory then it too would be 'good'. The choreographer is also mentioned as interpreting dance, because the choreographer is first the creator of a dance piece. Because the choreographer can state their intentions when creating a dance, they can explicitly outline what they intended the dance to mean. The viewer however, is left to interpret the dance themselves.

\section{Summary}

The evidence presented at the beginning of the literature review illustrates that dance has been used in museums for a number of years in numerous ways. Dance events at museums have served to entertain the public as well as interpret objects and display the performing arts of different cultures. The literature illustrates the role for dance in museums. Dance finds a place in the museum firstly as a form of intangible heritage, which can be displayed and interpreted, as indicated by the UNESCO Convention for the Safeguarding of the Intangible Cultural Heritage 2003.

\footnotetext{
${ }^{120}$ McFee, Understanding Dance.

${ }^{121}$ Myron Howard Nadel and Constance Gwen Nadel, ed. The Dance Experience: Readings in Dance Appreciation,(New York: Praeger Publishers, 1971).

${ }^{122}$ Kraus, History of the Dance in Art and Education.

${ }^{123}$ McFee, Understanding Dance, 153.
} 
Additionally, dance can also be used in museums as a unique experience for visitors. Firstly, dance can provide a participatory experience. This could appeal to groups of people visiting the museum socially, families, school groups and individuals seeking a new experience at the museum. Dance can also function as a form of dynamic narrative interpretation, allowing museums to tell stories through the expressive medium of dance. Museums can also use dance as an avenue to market the museum to new groups of people. Dance events can appeal to members of the community who may have previously felt excluded from the museum. Dance can also attract those people who are drawn to activities which take them out of their comfort zone, the fantasy adventure seekers identified by Scheff and Kotler. ${ }^{124}$ The literature outlines the many positive roles dance can play in the museum and the ways this influences the visitor experience. While the literature suggests the potential for dance to be used in museums, it highlights the lack of investigation into how these events work in the museum environment. The relationship between the dance companies or dancers, and the museum has not been investigated, nor has the impact these events have on the visitor. This is a gap which the current study aims to investigate.

The following chapter outlines the research question I have chosen to answer and the methodology undertaken to investigate it. The research focuses on the reasons why the case study institutions have undertaken an event which places dance in the museum environment. It also investigates the practicalities of these types of events, from both the perspective of the museum as well as the dance company. Overall, the relationship between the two institutions is explored, from the practical aspects to the interpersonal connections between staff. Finally, I also investigate the visitor's perspective of the event, which includes their take on the dance as well as how they found the overall experience at the museum.

Chapter three includes four sections discussing the findings from the interviews. These sections explore both the practical aspects of the event, as well as the philosophical reasons why the event was held. Throughout the sections the viewpoint of the visitor is included. Chapter four then discusses the conclusions of the research, as well as two areas which can be considered for further development.

${ }^{124}$ Scheff, Standing Room Only, 70. 


\section{Chapter Two: Research Design}

\section{Introduction}

This chapter outlines the research question and aims, as well as the method undertaken to investigate this. It examines the research methodology employed to answer the research question and the ethical implications of this. The chapter also explains the method of analysis for the research. Finally, the chapter describes the research population and the case study selected for the research.

My overarching research question is to investigate how contemporary dance can be incorporated in New Zealand museums. The first aim was investigate the practicalities of incorporating dance in museums. In doing this I hoped to identify both areas of success as well as the areas which were problematic. Secondly, I chose to investigate how those involved in the event related with each other in the workplace. Of particular interest was how the relationship between the two different organisations, and individuals, worked together despite being from different workplaces and industries. An audience member was also interviewed to investigate how different aspects of the event influenced their experience.

\section{Methodology}

For any research a methodology must be chosen which is suitable for the research question and for the researcher. Firstly, one must examine the philosophical standpoint from which the research is approached. ${ }^{1} \mathrm{~J}$ Creswell uses the term "worldview" to describe the "general orientation about the world and the nature of research that a researcher holds". ${ }^{2}$ The types of beliefs that the researcher holds will guide them in their choice of research method, whether that be a qualitative, quantitative or mixed method approach. ${ }^{3}$ A qualitative approach focuses on "exploring and understanding the meaning individuals or groups ascribe to a social or human problem", with the researcher interpreting conclusions from the data. ${ }^{4}$ A quantitative approach examines the relationship among variables, typically measured on

\footnotetext{
${ }^{1}$ J. Creswell, Research Design: Qualitative, Quantitative and Mixed Methods, (California: Sage, 2009), 5.

${ }^{4}$ Creswell, Research Design, 4.
} 
instruments and using statistical procedures. ${ }^{5}$ A mixed method approach combines aspects of both qualitative and quantitative research methods. ${ }^{6}$ Given that my research is focused on people's opinions and feelings, Creswell's "Social Constructivist Worldview" best fits this research project. Creswell writes that social constructivists "hold assumptions that individuals seek understanding of the world" and that "the goal of the research is to rely as much as possible on the participants' views of the situation being studied". 7 This is the most suitable approach to the research as the focus is on each participant's personal viewpoints and experiences of the case study event. This worldview also includes my approach to interviewing, where "the more open-ended the questioning, the better". ${ }^{8}$ This worldview was employed in analysing the interview data, as interpersonal communication will feature strongly and this approach addresses "the processes of interaction among individuals". 9 Consequently, a qualitative research approach was chosen, which Creswell defines as "a means for exploring and understanding the meaning individuals or groups ascribe to a social or human problem". ${ }^{10}$ Sotirios Sarantakos provides a useful list of general criteria for choosing a qualitative research methodology. The following criteria are specific reasons for choosing this methodology: ${ }^{11}$

- It tries to capture reality in interaction.

- It studies a small number of respondents.

- It employs no random sampling techniques.

- It perceives the researcher and the researched as two equally important elements of the same situation.

- It aims to study reality from the inside not from the outside.

- It aims to understand people, not measure them.

- It employs research procedures that produce descriptive data, presenting in the respondents' own words their views and experiences.

\footnotetext{
${ }^{5}$ Ibid., 4.

${ }^{6}$ Ibid., 4.

${ }^{7}$ Ibid., 8 .

${ }^{8}$ Ibid., 8 .

${ }^{9}$ Ibid., 8

${ }^{10}$ Ibid., 4.

${ }^{11}$ Sotirios Sarantakos, Social Research (Basingstoke, Hampshire: Macmillan Press Ltd., 1993), 45.
} 
In order to gain in depth and specific information a case study was examined.

Sarantakos describes case studies used in a qualitative methodology as the study of "social action in its natural setting as it takes place". ${ }^{12}$ I used both observations and interviews to examine the case study. The case study was a dance event held in a museum.

Observations: An observation of the event was chosen as the first step in the research process. Observations allow first hand information to be collected and provide an overall view of the event and its general running. Unobtrusive observations are useful because they "tend to assess actual behaviour as opposed to self-reported behaviour". ${ }^{13}$ This method of observation was selected as it allowed for observation of the social situation as it occurred naturally. ${ }^{14}$ Because I am employed by the museum the observation was not entirely unobtrusive. Staff members needed to be informed that I was present at the event to observe it for the purposes of my research project, not as an employee of the museum, and I was not paid for any work I did that night. Visitors to the museum would have perceived me to be an employee of the museum as I stood behind the front desk as this was the best vantage point for observing the front of house operations for the night. The observation conducted can also partly be defined as participant observation, as I was involved in the event on the same level as the audience members while the performance took place. ${ }^{15}$ The observations were used to developing the areas of inquiry for the following interviews. Data was collected using note taking throughout the event. I later typed up the notes, and included my overall reflections on the event.

Interviews: Semi-structured interviews were conducted after the initial observation of the event. An advantage of semi-structured interviews is that they are flexible. ${ }^{16}$ This was particularly important as a different interview schedule was designed for each participant. A standardised set of interview questions was not suitable for this research because each participant had a different role in the event. Because of this, an

\footnotetext{
${ }^{12}$ Sarantakos, Social Research, 261.

${ }^{13}$ Ibid., 231.

${ }^{14}$ Ibid., 231.

15 Ibid., 222.

${ }^{16}$ Ibid., 198.
} 
overriding set of aims for the interviews was devised (Appendix A), however each interview schedule was written individually.

For the first interview, I used information gathered from my observations as a basis for inquiry. Then, after each subsequent interview, I modified the interview schedule for the next participant, referring back to the observations and the over arching research question and aims. This emergent research design allowed for a set of interview questions specific to each participant and their role in the event. Each interview schedule was also reviewed beforehand, to make sure that each question was clear and easy to understand, and also to ensure that none of the questions were leading. Many participants also offered answers to questions unprompted as part of another answer. In these instances, I asked for them to expand on the point at the time but did not repeat the question later on. These unprompted answers were partly due to the working relationship already established with a number of the participants. This resulted in these interviews taking a conversational tone as the participants were comfortable with the situation. Each interview was recorded and digitally stored on my computer for transcribing.

\section{Ethics}

T. M Wilkinson writes that "the core idea of ethics in research is that one cannot justify imposing burdens on subjects simply by appealing to gains to others". ${ }^{17}$ Simplified, the benefits of the research will outweigh the potential burdens placed on the subjects. As a result of this, ethical considerations must be made in order to ensure that research participants are treated fairly.

Codes of ethics have been created within institutions to ensure that research is conducted according to ethical standards. ${ }^{18}$ In the case of this research, ethics were governed by the Victoria University of Wellington Human Ethics Committee (VUWHEC). An agreement was reached between VUWHEC and myself prior to commencing the research (Appendix B). This agreement focused on informed consent being obtained from each participant prior to their interview. In order to ensure this, a formal invitation and written consent form was issued to each participant (Appendices

\footnotetext{
${ }^{17}$ T.M. Wilkinson "The core ideas of research ethics" in Research Ethics in Aotearoa New Zealand: Concepts, Practice, Critique, ed. M. Tolich (Auckland, N.Z.:Longman, 2001), 14.

${ }^{18}$ Sarantakos, Social Research, 16.
} 
C and D). These documents outlined in advance the nature of the research and what it would be used for. Participants were informed that they were able to withdraw from the research before a specified date. Participants were also offered the opportunity to approve their interview transcripts before they were used in the research, and so all were emailed their interview transcriptions for approval prior to analysis. This also allowed for participants to edit their interviews, adding or retracting any comments they chose to.

Accordingly, informed consent was gained from each participant prior to commencing their interview. Heather Piper and Helen Simons define informed consent as ensuring that "those interviewed or observed should give their permission in full knowledge of the purpose of the research and the consequences of them taking part". ${ }^{19}$ Informed consent was particularly important in this research as no anonymity was offered to any of the participants. Because of the size of the dance community and the museum community in Wellington it would be unrealistic to try to disguise the identity of the organisations. In turn, the organisations themselves are small and disguising the identities of the research participants was also unrealistic. As a result, all participants were made fully aware that their full names and job titles would be used in the research. Because confidentiality and anonymisation of the participants is a common assumption in ethical practice participants were reminded of the lack of anonymity at every stage in the research. ${ }^{20}$ To ensure participants fully understood this it was made clear in the written consent form they were given. The consent form was also verbally explained to the participants prior to interviewing. This gave participants the opportunity to ask any questions or raise concerns regarding the research or how it would be used. To ensure that all participants were comfortable with the research, they were assured that the findings would be presented positively and respectfully. This was particularly important as comments made by participants potentially could have impacted on their relationship with colleagues or on their employment. Ultimately, all participants consented to participate in the research and upon reviewing their interview transcriptions, no participants withdrew from the research.

\footnotetext{
${ }^{19}$ Heather Piper and Helen Simons, "Ethical Responsibility in Social Research" in Research Methods in the Social Sciences, ed. Bridget Somekh and Cathy Lewin (London: Sage, 2005), 56.

${ }^{20}$ Ibid.,57.
} 


\section{Research Population}

The case study was suggested to me by my supervisor Brett Mason, who is also the director of the Museum of Wellington City and Sea, where the event was held. The case study was suitable for a number of reasons. It is a local museum, making it easily accessible for me. This also allowed for interviews to be conducted at the museum, which was convenient for the staff members. I was also employed at the museum at the time. This gave me access to the building and the staff. This was particularly helpful during the observations as I already knew my way around and the staff members did not question my presence at the event. Having decided that this would be a suitable case study, I approached the dance company, who also agreed to participate. Footnote Dance Company is also based in Wellington, which again allowed for interviews to be arranged in locations convenient for the participants.

The research population for this project consisted of those people who were employed in the running of the event. This included those employed by the Museum of Wellington City and Sea, Footnote Dance Company and any people contracted by either organisation to work on the event. I selected to interview only those staff members who were directly involved in the case study event. Also by interviewing every person involved a comprehensive view of the event was gained and all viewpoints were included. As a result, the initial research population was seven; however the interviews revealed more people were involved than initially anticipated, bringing the total number of interviews to ten.

There were two people connected with the event that were not included in the overall research population. The choreographer of the piece (Maria Debrowska) and the composer (Gene Alexander) were not involved at when the dance company and the museum worked together. While they were both aware that the work was to be performed in the museum, the work was completed in advance and neither visited the museum for the purpose of the creation of the piece. In total, ten interviews were carried out, including one interview with an audience member.

Though I had not originally planned to interview an audience member, many of the interviewees discussed how they thought, or assumed, the audience would perceive of 
the performance. As a result I decided to interview an audience member to see if the intentions of those behind the scenes were in fact perceived by the audience. Because neither of the case study organisations conducted their own visitor research, I relied on personal connections to obtain this interview. As a result, the participant was someone I know socially. This participant was chosen because he attended the event of his own volition (he was not given free tickets or asked to attend for work). He also regularly visits museums and dance performances and was therefore familiar with both case study organisations.

Participants were initially approached either in person or by email, and all participants were given a formal invitation to participate in the research. This invitation outlined the purpose of the research and provided information regarding ethics. As outline previously, the research was not anonymous, and this was also outlined in the invitation. Once participants had responded, a time was agreed upon for the interview. The interviews were carried out either at the participant's workplace, or at Victoria University of Wellington. Two of the interviews were carried out by phone as the participants had moved overseas.

\section{Limitations}

The first limitation of this research is that it is small case study. While the ten people interviewed made up the relevant research population, it is still a small number of people and therefore the findings cannot be generalised to apply to all museum staff or all dance company staff. Generalisations also cannot be made on a national level as the two institutions were both based in Wellington. A number of issues raised in the interviews cannot be applied to museums in general or dance companies in general as they are relevant only to the case study institutions.

A second limitation is that there was only one audience member interviewed. The first reason for this is that no data was collected by either institution to provide contact details for those who attended the event. This meant that it would have been considerably difficult to find audience members to approach to participate in the research. Also, due to time constraints priority was given firstly to those involved in the event internally, over those who came to watch the event. In order to find audience members, I sent a group email out to the community dance groups I have 
been involved with in the hope that a member had been to the event. Through this I discovered that two people I knew had attended the event. I contacted them both, sending an invitation to participate in the research. One declined, allowing me only one interview with an audience member. However I have included comments made by staff members who watched the performance.

The research is also limited by the case study not being an ideal example of site specific dance. Because the piece was choreographed separately from the museum and was not directly inspired by the museum exhibitions or collections it is not truly site specific. However this limitation was overcome, in part, by the artists recognising that the museum environment did impact on the piece, which made it site specific in their opinion.

\section{Analysis}

In order to analyse the interviews I first transcribed them in full. At this stage the transcriptions were verbatim, with notes regarding intonation. Some participants drew something as a diagram to provide extra explanation. This information was kept and noted in the transcription. These transcriptions were then given to participants, so that they could approve them before they were analysed. Following this, I created a map of the relationships between each interview participant and how they interacted during the event. This provided a better understanding of each participant's specific role in the event, and who they interacted with during the course of the case study. Following this, I identified eight topics, or types of comment, that occurred in multiple interviews. The eight topics were created by looking at what comments were made by various participants and where they overlapped. Firstly, instances where multiple participants had made comments on the same issue were identified. In doing this I was able to identify each participant's views on that particular issue and compared them against others. This allowed me to identify the various facets of a particular issue and how it was dealt with or experienced. Following this, I refined the eight different topics into four wider ranging themes. The four themes identify the key areas I identified as vital to understanding the event. They identify areas which were both successful and those which were problematic. They also provide a way of understanding the event from each participant's perspective, and how their involvement was linked. 
Reflexivity can be used by the researcher to examine their own subjectivity and the impact they have had on the research data. ${ }^{21}$ Reflexivity can be defined as combining "the process of reflection with self-critical analysis". ${ }^{22}$ In employing reflexivity the researcher can better explain how their conclusions have been influenced by their own personal experience and viewpoints. In this research project, my methods have been heavily influenced by my first hand experiences being hired by a museum as a performer (Real Hot Dance Moves, 2010, see page 1). Having had that experience I was able to see that it was the interpersonal relationships between the people involved in the event that shaped the way it played out, and also led to its ultimate success. These observations sparked my interest in the field and then guided my strategy for researching the case study through interviewing those involved in the event. By visualising the event as a puzzle, each participant was identified as playing a specific role in the event as a whole. Connections between each person were made in order to establish a chain of command for the event. As such, themes and areas of interest were identified and compared, as were people's individual viewpoints regarding these themes.

The findings of the research are also entirely based on my interpretation of the content of the interviews. I have attempted to make as accurate an analysis as possible, while still affording consideration and respect to those interviewed and the institutions they represent. I also kept a research diary throughout the course of the project. This enabled me to consider how I approached the research at every stage and to reflect on the different aspects of it. Because of my personal connection to the project and many of the research participants, keeping a diary also helped to analyse the interviews while taking into account my personal viewpoint on them.

\section{Summary}

This chapter has articulated my research question and aims. It has also outlined the methodology undertaken to investigate this question, and the method of analysing the results. I have also included why the case study was chosen and the limitations of this study. The ethical implications of the research have been outlined, including

\footnotetext{
${ }^{21}$ Bridget Somekh and Cathy Lewin, Research Methods in the Social Sciences (London: Sage, 2005), 348.

${ }^{22}$ Ibid.
} 
outlining that the research was not anonymous and why. The following section provides the background to the case study. It outlines both of the institutions and the relationship between the two. It also provides background information on each interview participants. This includes what their role was in the event, and any personal information which they provided in the interview.

\section{Introducing the case study}

The case study used for this research project was the performance of Standing Birds by Footnote Dance at the Museum of Wellington City and Sea in October 2010. The performance was part of Footnote Dance's Forte Season for that year. This section provides background information on both the Museum of Wellington City and Sea, and on Footnote Dance. It also provides information on the Forte Series and more specifically on Standing Birds, the dance piece performed at the museum.

Additionally, this section provides a profile of each interview participant. I have chosen to include personal information about interview participants where relevant. This information was given by the participants, unprompted, in their interviews, because they believed it was relevant to their experiences at the event. A disc containing the video files of the Footnote Forte Season 2010 in Wellington has been included courtesy of Footnote Dance Company. The performance Standing Birds is the first performance on the disc. This provides wide angle footage of the performance.

\section{The Museum of Wellington City and Sea}

The Museum of Wellington City and Sea is situated on Queens Wharf, in the Wellington Central Business District. Located in the Bond Store, the museum was originally a Maritime Museum, and still has a strong maritime focus. However it now also includes the social and cultural history of Wellington city. It is a part of the Wellington Museums Trust. For Brett Mason, the Director, the museum is " $a$ community museum that brings in the stories of the different members of the community...we hold and care for the objects or the collection of the community".

\section{Footnote Dance}

Footnote Dance is a contemporary dance company based in Wellington. Footnote Dance employs New Zealand dancers, choreographers and musicians and collaborates 
with a variety of other New Zealand organisations. The company also provides dancein-education programmes, which travel throughout New Zealand schools. Footnote Dance is primarily funded by Creative New Zealand, as well as Wellington City Council and other charitable trusts. Director Dierdre Tarrant emphasises the focus on local artists, saying that "the major philosophy is that it's New Zealand work, made by New Zealand choreographers, to New Zealand music”.

\section{The relationship between the institutions}

The museum and the dance company have a long history of collaborative work. The two directors have a long standing professional friendship, which has led to numerous collaborations. Previous work includes work choreographed by Footnote Dance to accompany the museum exhibition War in Paradise, in 2007.

\section{Footnote Forte Series}

The Footnote Forte Series is a season of public performances by Footnote Dance. The performances are deliberately held in non-traditional spaces. For the 2010 series, the pieces were based on the theme of environment, both physical and social. The Forte Series in Wellington involved audience members attending dance performances at three different venues. The first performance was held at the Museum of Wellington City and Sea. The audience then walked, accompanied by members of Footnote Dance, to The Boatshed, which is situated on the Wellington waterfront. After that performance, audience members and Footnote Dance members travelled on foot to the Museum Hotel, situated on Cable Street. A different piece was performed at each venue, by a number of different dancers. At some venues the piece would be performed twice, to ensure that all audience members saw the performance. This was because the venues were not set up for large audiences and visibility was a problem.

\section{Standing Birds}

The piece performed at the Museum of Wellington City and Sea was called Standing Birds. The piece was choreographed by Maria Debrowska, and set to music by Gene Alexander, both of whom are from New Zealand. The piece was performed by two dancers, Jeremy Poi and Anita Hunziker, and used a chair as a major prop. Please refer to the $\mathrm{CD}$ provided for more detail. 
For the following sections, each institution will be referred to by a shorter name based on the names used by the interview participants. The Museum of Wellington City and Sea will be shortened to Museum of Wellington, and Footnote Dance Company shortened to Footnote. They will also be referred to as the museum or the dance company, as this is the way a number of interview participants referred to their own place of work.

\section{Interview participant profiles}

Each interview participant carried out a different role in the case study performance and their personal backgrounds influenced the way they experienced the event. As a result I have provided a brief personal profile for each interviewee, stating their job title, their role in the case study and any personal background information relevant to the case study. For the following sections, interview participants will be referred to by their last name only.

Brett Mason: Director of Museums Wellington. ${ }^{23}$ Brett was involved in the initial planning stages.

Paul Thompson: Experience Manager for Museums Wellington. Paul was involved in planning the event.

Mark Attfield: Building and Facilities Manager for Museums Wellington. Mark was involved in planning and managing the event.

Carrie Green: Children's Experience Host at the Museum of Wellington. Carrie worked front of house on the night of the event. Carrie is a second year acting student at Toi Whakaari, the New Zealand Drama School. She is also a trained dancer.

Dierdre Tarrant: Director of Footnote Dance Company. Dierdre was involved in planning the event and also ran the event on the night, including operating the sound and lighting equipment.

\footnotetext{
${ }^{23}$ Museum Wellington refers to a grouping of three institutions within the Wellington Museums Trust. The three institutions are the Museum of Wellington City and Sea, the Cable Car Museum and the Colonial Cottage Museum.
} 
Anita Hunziker: Contemporary dancer for Footnote Dance.

Jeremy Poi: Contemporary dancer for Footnote Dance.

Nina Baeyertz: Administration Assistant, Footnote Dance. Nina was involved in planning the event and filled the role of Production Manager for the event. Nina is also a trained dancer.

Doug Bonnelack: Freelance Lighting Technician. Doug was hired by Footnote Dance for this event.

Andrew Campbell: Audience member. Andrew works for the Green Party, is a semiprofessional dancer and regularly visits museums and attends other performing arts events.

\section{Further Definitions}

For the purposes of this research both terms visitor and audience member will be used to describe those people who attended the dance event. Visitor is the term most commonly used in museum literature, and audience member most commonly used in performing arts literature. As such, both terms will be used where appropriate.

Contemporary Dance: Contemporary, or modern, dance can be defined as placing "emphasis on the artistic expression of the individual performer". ${ }^{24}$ Contemporary dance began as a rejection of the structure of traditional ballet and continues to lack a single approach to technique. It is highly disciplined and skilled however, and bases its technique on "natural movement" of the body. ${ }^{25}$

Chapter three outlines the findings from the interviews. The findings have been divided into four sections. These sections are the four overarching themes which were identified in the interviews. Each sections incorporates comments from both the Museum of Wellington interviewees, and from Footnote. I have also included comments from the audience member interview.

\footnotetext{
${ }^{24}$ Kraus, History of the Dance in Art, 119.

${ }^{25}$ Doris Humphrey, “America's Modern Dance”, in The Dance Experience, eds. Myron Howard Nadel and Constance Gwen Nadel, (New York: Praeger Publishers, 1971), 106.
} 


\section{Chapter Three: Findings}

This chapter examines the findings from the interviews. The four overarching themes which were taken from the interviews make up the four sections of this chapter. The first aim of my research was to investigate the practical aspects of holding a dance event in a museum. As such, the first two sections of this chapter cover the practical issues which were raised in the interviews. The first section, "Benefits and Barriers", covers the tangible benefits to the museum and the dance company, as well as any barriers which could have prevented the event from happening. The following section, "Areas of Concern", covers the three main aspects of the event which were problematic for both institutions. The next research aim was to look at the overarching reasons why events of this nature happen, and the impact they have on the visitor. The third section of this chapter discusses the connection between the museum and the dance company. This also includes the connection between the piece and the museum exhibition perceived by the audience. The final section discusses the overarching reasons why the museum and the dance company held the event, and the impact this had on the visitor.

\section{Benefits and Barriers}

The following section will discuss the practical and tangible benefits to both the museum and the dance company identified in this case study. In this discussion we also cannot ignore the barriers which could prevent dance being incorporated in museums. In recognising these barriers we can seek to find practical solutions for future events of this nature.

The museum is obliged to create and maintain relationships with other arts and community organisations. While this is not a benefit to the museum as such, bringing the dance company into the museum fulfilled obligations important to the museum. It is museum policy to work with local community and interest groups (See Appendix E). It is also museum policy to hold public programmes which should appeal to a wide range of audiences, both education and recreational (Appendix E). As a result, incorporating a dance event in collaboration with another Wellington based arts group fulfils the museum's policies regarding education and public programmes. The 
2010/2011 Statement of Intent for the Wellington Museums Trust (as a Wellington City Council Controlled Organisation) also outlines community engagement as a priority (Appendix F). Developing and maintaining relationships with community groups is a goal for the organisation. This aligns with the Wellington City Council's goals of engaging with grassroots, community and youth-oriented arts and cultural activities.

Mason and Thompson also identify that dance can be used as an innovative method of interpretation. Mason sees storytelling as an important role in museums and that the "storytelling comes in lots of different ways". Drawing on this idea, dance becomes a potential method of interpretation of objects. Thompson draws on Howard Gardiner's theory of different intelligences, and sees dance as a way for the museum to appeal to visitors "across a range of interpretive strategies". Thompson looks at the different interpretation methods in the museum saying "some are text based, such as labels, some are visually based such as looking at objects, and the dance one for example was kinetically based". Here, dance becomes another way for the museum to interpret objects. Though this case study was not a direct interpretation of the objects in the museum, those interviewed acknowledge that this had been done in the past.

Following on from this, dance can be used to draw in new audiences, a major objective for museums. ${ }^{1}$ Audience development is the process of identifying different audiences and then providing a museum experience for that audience. Mason identifies dance as a way to draw new audiences into the museum. "For me it's always about audience development...you're trying to show people that the museum's not just a museum and that's why we do these different things". Hosting a dance event will draw in people who are interested in dance as well as people who are interested in the museum. Mason also recognises that Footnote and Tarrant have their own following, "she has her own audience and she brings that audience with her". In relation to audience development Mason also says that "one of the other plusses is for profile raising". This means the museum can latch on to the publicity the event creates. This means the museum is being publicised without using its own budget or doing any work. By bringing in new audiences and raising the public's awareness of

\footnotetext{
${ }^{1}$ Ruth Rentschler and Anne-Marie Hede, eds, Museum Marketing: Competing in the Global Marketplace. (Oxford: Elsevier Ltd.,2007), 43.
} 
the museum, Footnote have benefited the museum directly. There are also tangible financial benefits for the dance company. For Footnote, money can be saved on venue hire. Tarrant states that "our costs for venues outweigh our artistic costs" and that the idea for the Footnote Forte Series was born out of this situation, with Tarrant wanting to "specifically do performances in different spaces".

While the above benefits could apply to any dance company in any museum, there were also specific benefits that came with this particular case study. For the museum, the benefit is the relationship between the two institutions. Mason believes that as a "community museum" in Wellington, the museum has a duty to "allow a place for dialogue for those communities". By having Footnote performing in the museum, voice is being given to the dance community in Wellington, and Mason believes that "it shows us being actively supportive of the community". For Footnote, the benefits lie in the influence the museum has on their artistic process. The environment at the Museum of Wellington has specifically influenced their choreography and performance. Both dancers comment on the museum environment and its influence on their performance, with Poi stating that the dance "takes on a different life" in the museum. Also, Huntziker noted the way the dance fitted into the environment, that "the nature of the piece is so intimate...that environment really suited it, the audience being able to be so close."

Both Baeyertz and Tarrant mention the 'feeling' a person gets in museums and the Museum of Wellington in particular. Tarrant talks about the Bond Store exhibit as being like a tunnel, "you know that psychological thing of going on an aeroplane when you shut your environment down until you reach the action". This, combined with the staircase, created a degree of expectation for the audience "which you don't get when you just sit in a space". The museum environment shaped the visitor experience before the performance had even begun. Baeyertz also comments on the way the museum environment gives dance a sort of authority or weight, as if the museum somehow validates the performance, saying "I think that placing something ephemeral like dance within that context...somehow it's weighting it in history". Indeed, the dance is given authority by the environment that surrounds it. This is not uncommon. Museums (and art galleries) have long been seen as an authority on culture. 
There are also significant barriers to having dance in the museum environment. Lack of space within the museum featured prominently in the interviews as a reason why dance would not work in the museum environment. Thompson says that "in a museum, especially a museum like this, the spaces are rather constrained" making it difficult to perform dance routines. Tarrant reiterates this, saying that the museums are "difficult spaces" from their point of view. For Poi, the issue is that the dancers "don't get to do the dance exactly how we've rehearsed it" because there is not enough space to move around. Therefore, the lack of space is a negative both practically and artistically, causing a change in the end performance of the dance.

The barriers for the museum are also practical issues. The museum made no financial gain from the case study performance. Mason states that financially "it was just a cost to us, not a gain" because the museum loses money through staffing and other costs, but does not recoup this money by charging visitors or taking a percentage of ticket sales. There are also barriers which apply to the museum in regards to the visitor experience. Mason comments on how the dance changes the running of the museum because "you can't have the museum running, properly" and that this means the visitor is not "getting the full museum experience".

The interviews revealed a number of barriers which could have prevented the event from going ahead. For the museum, these were primarily practical issues, for example the lack of financial return, which does not cover the cost of the event. For the dance company, concerns over space were observed by the dancers and those organising the event. Though these barriers are by no means unimportant, the benefits for both institutions outweighed them. For the museum, the benefit lies in audience development and the collaboration with another arts institution. For the dance company, the practical benefit is that money is saved on venue hire. The dance company also benefits from the collaboration and the opportunity to perform in a unique space. 


\section{Areas of Concern}

Following on from the practical issues regarding the planning and running of the event, this chapter investigates what I have called 'Areas of Concern'. While they are not barriers preventing dance being used in museums, they are issues that were problematic for the organisations in the case study. Using the observations of the event, some interview questions were formulated to question areas which stood out as not running smoothly. For example, I observed that the front of house area was disorganised. Baeyertz and Green did not have a system for ticketing and neither communicated to the other who was doing what. As a result the front desk appeared to be chaotic. Secondly, the location of the dance raised questions of both object and visitor safety. There were also a lot of people crowded on the staircase in the museum, which could potentially be a risk in an emergency evacuation. The performance also appeared to pose a risk to the model of the ship, the Pamir, which was located behind the dancers. As a result, safety and communication were the two areas I highlighted as problematic after the observations. Also, the issue of how to measure the success of the event came out of the interviews. This was because all of the interviewees thought that the event was successful, but for different reasons. This section will discuss these three areas of concern, looking at how they manifest themselves in both organisations. It will also look at any suggestions made by the interview participants for resolving these concerns.

\section{Safety}

Safety issues arose within the museum during this event because the facility was not designed for dance or any other performances. For Attfield, object safety was his "biggest concern" for two different reasons. Firstly, large objects nearby may be damaged by the dancers, stating that "the dance thing, was right next to the Pamir model, which is a huge object that's not protected by glass". He was also concerned that smaller objects could be displaced by the movement of the floor due to the jumping of the dancers.

Thompson discusses safety with groups working in the museum in the initial planning stages, saying that he would "go to the space with them of course, talk to them about it, or about its suitability and when we're standing there we look at those things - are there any objects in danger? " Reinforcing this 'case by case' approach Mason states 
that there has "never been a policy" but that staff members know the rules regarding object safety in the museum, suggesting that it is up to individual staff members to make use common sense in regards to object safety.

Aside from the protection of objects, there are other safety concerns within the museum. The museum uses a variety of audio visual displays with a system unsuitable for larger scale productions. Attfield states that the museum has to be "very careful of what we allow... because our gear's ten years old. And when they put a huge load on it like that it doesn't like it." In this instance the issue was solved by Footnote bringing in equipment for the performance. Bonnelack states that this is not unusual when working in spaces that are not purpose built, with his main concern being that the equipment is "safe and not taking up too much space".

There are also important safety issues for the dancers, with flooring being a particular concern. Bayertz says that she was always "aware of floor surface" when choosing the location of the performance in the museum, as a wooden floor is preferable for dancing on. The floor at the Museum of Wellington was suitable, as it is wooden. Nevertheless, Hunziker did note that "that one was a little bit too gappy and I ripped a couple of toenails". Though not a major safety issue, this does highlight that injury is a real concern for dancers working on non-dance spaces.

The interviews revealed that while the safety of the objects and the dancers is an issue, the museum staff and the dancers strived for practical solutions to ensure that the performance could go ahead, or in the case of Hunziker, carry on regardless of injury. In this case there were no incidents involving damage to the objects or museum equipment, and minimal injury to the dancers, which is a positive result.

\section{Communication}

Communication within and between the two organisations was important in the running of the event. Administration assistant and production manager for the event Baeyertz recognises the importance of inter-organisation communication as she says "that was probably the first important thing that I did...just to be there to connect all three people together". The planning for the event began with communication between the two directors, with Mason stating that it was "really because of the 
historic nature of our relationship". Communication after that point was primarily between Baeyertz and Thompson as both Mason and Tarrant were overseas at the time. Baeyertz notes that there was confusion over what was happening at first, starting "on the back foot with communication between the museum and the company". While this made things difficult she recognises that it was " $a$ breakdown... within Footnote and within the museum" which was resolved quickly. Green however, felt that these gaps in communication continued and she was not given ample information on the night. Green "would've liked some more information about the programme itself, as to what was happening". This would have allowed things to run more smoothly. She also says that it would have been beneficial to have better communication from all levels "rather than the information being filtered down", ensuring that everyone knows what is happening on the night. Some of the gaps in communication were a result of the two different industries coming together. Bonnelack, the lighting technician for the event, recognised this and gives the example of "packing out"2 as an area where this arose. Normally, pack out would occur directly after the performance, but in this case he had to wait until the morning after as staff at the museum needed to go home. He notes that this is not a personal issue, but that 'it's just different industries...either he [Attfield] didn't appreciate that your industry operates different or we [Footnote] didn't appreciate that he did [operate differently]" The lack of communication between staff members was noticed on some level by Campbell who said that "it seemed quite cluttered and busy" on the front desk. He said things "did sort of seem a little bit disorganised". The lack of communication between Baeyertz and Green resulted in disorganisation which was apparent to the visitor. As seen before with safety issues, though there were difficulties in the event, the issues were worked through and solutions found so that the event could go ahead. This is recognised by Baeyertz, who says "it was really important to keep remembering why we were doing it...I think that was the strongest part of the communication".

\section{Measuring success}

As museums and other arts organisations are increasingly being held accountable for how they use their funding, measuring the success of events such as this becomes

\footnotetext{
2" Packing Out" is the term used to describe the removal of all equipment (sound, lighting, props, costuming etc.) from a venue when the run of the performance or show is complete.
} 
paramount. One question asked of the interviewees involved in working the event was "Did you think the event was successful", with participants answering yes, but for very different reasons:

It was well attended and everyone came out saying really positive things, so that's successful for me (Green).

I think it's more about the relationship for a starter, and it's a continuation of that (Mason).

There were lots of people there who...had never been to one dance show, and two who had never been to the City and Sea museum so it was a kind of a winwin (Poi).

These, however, are all personal opinions or based on anecdotal accounts from people involved. On probing further it was revealed that there was no formal visitor research conducted by either organisation to confirm their opinions. Any comments made about audience opinions were anecdotal, with Baeyertz "really only guessing" when it came to audience information. Measuring success in these situations can also be problematic as it is difficult to quantify what success is. As illustrated by the above comments, there are different indicators of success and also different ways to measure it. The simplest measure is to count how many tickets were sold, or how much money was made from ticket sales. These are tangible results, which can be measured against other similar events however Mason admits that this is problematic. He believes that success "can be slightly immeasurable" because for him, the relationship between the organisation is most important, not the number of tickets sold, and this is not quantifiable. There were also practical reasons as to why audience research was not conducted on the night. I observed that it would be difficult to implement an exit interview as the audience moved around different venues and there was no specific exit point at the Museum Hotel, the final venue for the night. Furthermore, the programme booklet was an added extra which visitors paid for. This meant that not every visitor received one and had there been a self-complete survey included, the sample would have been small and not entirely representative.

Both organisations do recognise that audience research is an area to be addressed in the future, with Mason saying that he "hadn't actually thought about it but it'd be really interesting to do it" and Baeyertz commenting that Footnote is "putting in 
more processes" for audience capture information. Again practical issues are a factor, with visitor research being costly and time consuming. It was this lack of visitor feedback that motivated me to interview a visitor. While Campbell did not feel that he fully understood what the dance was about, his overall experience was a positive one. Ultimately he says that "the key reasons that I loved it, was that I loved that it was in different spaces, I thought that was really interesting." Campbell's comment acknowledges that the fact that the performance was in a different environment made it interesting. Given that Footnote's motivation for the event was to put dance in different spaces, then this statement is surely an indicator of the success of this event.

While the quotes presented in this analysis are direct from the interviews, it is impossible to convey the overall tone and intonation of those interviews. One thing that stands out in listening to the actual interview recordings is that while people mention different issues, or concerns, they are never negative or critical; instead they simply observe that these things occurred and more often than not, offer a solution in hindsight. This positive reaction to the event highlights the good nature of the relationship between the organisations and the hard work of those involved. Mason puts this relationship down to the years that the two institutions have worked together, and knowing that his team will consult him if there are any issues.

\section{Connecting Dance and the Museum}

The following section discusses how audience members perceived the relationship between the dance itself and the museum. Based on the observations of the event I saw no obvious connection between the dance routine and the content of the museum exhibition. The dance was performed on level one of the museum, which is a maritime themed area titled By the Sea We Live. The dancers performed in front of a large model ship (The Pamir). The model ship behind them was lit, drawing attention to it, as well as the area where the dancers would perform. The dancers performed on the floor, with the visitors standing around them in a semi-circle. The choreography of the dance itself did not seem to link to the content of the museum exhibitions around it and there were no interpretation tools to assist the audience in understanding what the performance was about. The physical environment of the museum impacted heavily on the way the audience viewed the performance. There was no seating, and 
visitors had to find their own place to stand. Because the dancers were at floor level it could be difficult for visitors to see the performance clearly. People also stood in the alcoves of the museum, or sat on the staircase. The close proximity of the audience to the dancers added to the forceful choreography of the dance, with some visitors backing away from the performance if they felt too close. This physical reaction to the performance demonstrated that the visitors were engaging with the dance on some level.

My observations of the event led me to question the link between the dance and the museum, and whether the artistic intention of those planning the event was perceived by the visitor. Firstly, Mason believes that visitors do not see the collaboration between the museum and the dance company, stating "I don't think they [the audience] see the collaboration". Mason sees this as a problem because for him the relationship being developed between the institutions is an important reason for having these collaborations. One reason that visitors might not see the connection is that it is occurring between the organisations. Visitors are not able to see the creative process where the two organisations meet and decide on how the event will work. This may not be the sole reason however as staff members were also unable to see the collaboration with Green commenting that the situation was like "the dance company was hiring out the museum to use it as a space”.

The second aspect of the connection between the dance and the museum is that audience members did not see a thematic link between the dance and the museum. The piece, 'Standing Birds' was choreographed as a take on the physical environment that two people inhabit, using a chair. While the piece was not explicitly nautical or maritime themed, Tarrant saw the connection to the museum in this way:

the finished work for me had all sorts of ramifications if you like of settlers and people arriving, and maybe transit, that whole thing of you come with your most precious possession and nothing else and your most precious possession presumably is your partner and maybe one thing... and that's the chair.

Tarrant sees the piece as a result of its surroundings and that the dance "flows out of that set of parameters". Thus, the meaning of the piece was altered by what was around it. We can contrast this with a static artwork, where the piece is created and 
placed in the museum environment, but does not change as a result. In comparison, the dance piece is created by the choreographer, but its location in the museum altered the way it could be performed, and the choreography was changed to fit the space. The interpretation of the piece is also altered by the location and the choreography "sort of amorphosed into a piece really about sharing space" (Tarrant).

The location for the piece was also carefully chosen with visitor perception in mind and with Tarrant aiming to change "the perception of how people were going to view something as well as changing where they viewed it". So not only were visitors placed in an unusual environment, the museum, they were placed in a challenging space within the museum as well. The space was "forcibly intimate" according to Campbell, and Hunziker thought the space "really suited" the choreography as it placed the visitor very close to the dancers and on the same level. Tarrant also thought that the closeness of the audience to the dancers forced them to watch the performance regardless of whether it made them uncomfortable, comparing it to watching movies and avoiding watching the horrible bits. In the museum environment however, the audience members cannot look away or avoid the dancers because "you can't do that if your environment of performance is the same as the environment of observation" (Tarrant). This differs from sitting in a theatre where a person is distanced from the performance, usually in the dark, allowing them to close their eyes and shut out the performance without being noticed.

Poi not only recognised that the audience are aware of their being visible, but also that being so close to the action adds another sensory element because they can feel the sweat of the dancers. He said:

We can see the audience really clearly, they can see us, they know that we can see them and they're so close...they catch my sweat you know what I mean? Yeah that kind of experience is like, it's a more different kind of feeling.

The multi-sensory experience acknowledged by Poi is one of the ways in which the performance, and the dancers, could connect with visitors which is different from a traditional dance performance. In both museums and theatres there is a code of behaviour and an order of events which visitors expect. Both places generally demand a level of quietness and order. In a museum a visitor will walk around, perhaps read labels and view objects, and expect to learn something new. In a theatre an audience 
member will walk in, find their seat, observe and then leave. Both experiences require the visitor to observe something, but from a distance, either with the glass of a museum case, or with the distance of the stage in a theatre. Here, the experience of being so close to the live action that you can feel the dancers sweat is completely different from a traditional, or normal, experience at either site.

The comments made by Tarrant and Poi highlight that the dance company is acutely aware of the impact of location on the audience's perception of the piece and as a result consciously chose locations which would challenge the way the audience viewed the piece. I have included comments from Green here also, as she made an effort to go and watch the piece while she was working. She joined the general audience to watch the piece and had no prior information about it to aid her interpretation of what she saw. The artistic intentions of those involved are clear; however the connection between the dance and the museum may not have been clear to those who watched the performance.

I didn't see how the performance related to the space (Green).

It didn't seem to me to relate to that particular area of the museum (Campbell).

These two comments illustrate that on observing the museum environment where the performance was positioned, neither Green nor Campbell felt they saw any connection between the choreography and the content of the museum exhibition space. Campbell also expresses that he was expecting something with a nautical theme or a link to the sea, because the museum is known for its maritime theme. Both Campbell and Green however, make comments about how they shared their environment with others:

It made you interact with the rest of the audience as well and not all of that interaction was dance related (Campbell).

I think the thing I did like about it was that it was a very confined space (Campbell).

There was kind of a shared community feeling to it almost just in the configuration of the space (Green). 
If we refer back to Tarrant's comment that the piece is about "sharing space" then these comments illustrate that Green and Campbell were in fact engaging with the piece. Because the physical environment of the museum dictated the way they viewed the performance it made them share space with other people, and it is here that Campbell and Green engage with the meaning of the piece. Interestingly, the two audience members dealt with this issue in different ways. Green was not concerned with missing the thematic connection, saying that she "might have just totally missed the point because it's dance and it's hard to interpret" which she laughs about in the interview. Campbell on the other hand, saw it as more of a problem, saying he "didn't think it was an effective use of the space”. This is perhaps because one of his main motivations for going to the event was to experience dance in a non-traditional space and because he didn't see the connection he felt that his expectations had not been met.

Here, the physical environment of the museum is defining the visitor's behaviour by causing them to have conversations as they walked between venues. This is recognised in museological literature as an important part of the learning and meaning making process within museums. Conversations in museums are recognised as an important part of visitor learning and meaning making. Falk and Dierking write that "humans make sense of the world through social interaction with others, through distributed meaning-making". ${ }^{3}$ Campbell mentions the conversations he had with people numerous times in his interview. These conversations occurred during the time when the audience walked between venues, and Campbell comments that they were "reviewing the dances as it went".

The physical space of the museum also created a "community of learners". Though lasting only a short time, Green recognises that the group felt like a community because of the situation they were in. Falk and Dierking write that a community of learners is "defined by the boundaries of shared knowledge and experience." The audience members at the dance performance were bound by their shared experience, both in the museum and as they travelled together to each venue. On this level, as

\footnotetext{
${ }^{3}$ Falk, Learning from Museums, 38.

${ }^{4}$ Ibid., 46.

${ }^{5}$ Ibid., 46.
} 
members of a learning community and by sharing space with others, Campbell and Green both engaged with the meaning of the piece even if they did not realise it. Their learning and meaning making was influenced by both their physical environment and social interactions, which Falk and Dierking identify as two of three contexts which influence museum learning. ${ }^{6}$

\section{The "why we do it"}

Despite the barriers which could potentially prevent the event from happening, both organisations worked hard to push the event forward. When asked about how the relationship and communication between the museum and Footnote worked, Baeyertz made this statement:

It was really important to keep remembering why we were doing it...I think that was the strongest part of the communication.

This statement highlights that while there are more quantifiable benefits for both organisations, there are also overarching, less tangible factors which drive the relationship between the two organisations. It is these overriding reasons to carry on that push the organisations to overcome the barriers which could potentially prevent the event from taking place. This section will discuss the overarching reasons expressed in the interviews.

\section{Changing Perceptions}

Changing people's perceptions featured prominently in the interviews. From the museum perspective, Mason was primarily concerned with challenging traditional views of museums and using dance to "open up the concept of what a museum is". He believes that compared to the traditional viewpoint of a museum as solely a storehouse, "a museum in a more contemporary context is one where you have an object and a story that belongs to that object". Having dance in the museum will position it as a more dynamic place, movingg away from the perception that the museum is a storehouse for objects. For the dance company changing perceptions meant challenging the idea that dance must be performed in a theatre and according to Poi having dance in the museum challenges "the whole stereotypical thing of dance having to be in a little black box". In holding this event both organisations

\footnotetext{
${ }^{6}$ Falk, The Museum Experience, 99.
} 
endeavoured to change the way people see them by challenging stereotypes. In the pursuit of challenging stereotypes, the two organisations seek to show people something they have not seen before and Tarrant sees surprising similarities between the two organisations as a result of this, saying that "museums open a whole lot of doors to things that you otherwise might not see, but then I think contemporary dance does the same thing...it sets up to create pathways to communicate”. Campbell himself states that having his perceptions challenged is positive and a motivation for attending these types of performances. He says that he is "so used to seeing performance in traditional spaces. I personally like having that somewhat frustrated a little bit" which illustrates his desire for a more challenging experience.

\section{Growth for Artists}

Baeyertz refers to a 'creative magic' invoked by the combination of the objects in the museum and the dance performance and says "I think the magic is great...the aura of the objects...yeah like a creative magic". Having dance in the museum environment benefits the dancers artistically by providing a unique environment to work in. Huntziker says that the museum environment provides inspiration and that "you can draw on so much because there's visually so much around you and these interesting spaces", therefore the museum environment is providing inspiration for the artists. Tarrant agrees, saying that although the audience will interpret a dance piece or an object in their own way, "you also have the protagonist, the artists, changing that at the same time". The artists are not performing in a vacuum and will be influenced by the things around them. Specific to the case study, the choreography for Standing Birds was confrontational, and consisted of two dancers. Tarrant remembers that "every time they did it they'd have lots of conversations afterwards about who won today". Each performance was different and was potentially influenced by the environment, including the audience members. In drawing on what is around them in the museum, the dancers are changing the piece so that every performance is different, "sometimes Anita [Hunziker] felt she really got the upper hand and sometimes Jeremy [Poi] just felt he never got a chance." The museum also grows as Footnote "positions the museum as a facilitator of creativity rather than a storehouse of objects" according to Thompson. This not only changes people's perceptions of the museum, as discussed earlier, but also allows the museum to participate in the artistic process of the piece. 


\section{"You can't deny the quirk factor"}

In the words of Baeyertz when it comes to dance in the museum "you can't deny the quirkfactor". It is the fact that there was a point of difference from a traditional theatre performance that drew audience members in and made the performance something special. This is reinforced by Campbell, whose main motivation for going to the performance was that he was "really curious about using non-traditional dance space I guess, so spaces that I had been to in other forums". His other motivation was that he was interested in attending a performance which was different to "just kind of showing up and sitting down and then leaving”. In this case, the fact that the performance was unusual and "quirky" was its point of difference from other dance performances on offer. Baeyertz recognises that this is a way to draw audience members in, saying the quirk factor is "a real advantage, the fact that just because you're doing it, you're putting dance in the museum, and people will be interested because it's something different" This refers back to the marketing theory in the Literature Review, outlining how visitors are seeking unique experiences. Campbell too noted that it was the unique nature of the event, saying he was "curious" to see how it worked and this motivated him to attend.

\section{Telling Stories}

Having dance in the museum provides the museum with a different way of telling stories. For Mason, this is a priority, stating that he sees museums as "places of storytelling, and that storytelling comes in lots of different ways". Mason also sees storytelling as a similarity between the museum and performing arts organisations. As mentioned earlier in the Literature Review, both museums and dance utilise narrative to tell stories. As a whole the Footnote Forte Series functioned in much the same way a museum visit would. Campbell saw that people would "think, stop and reflect and then move on to the next bit" throughout the evening, which is similar to a museum visit where people stop at an object or display, think about it or read something, reflect on what they have seen and move on to the next exhibit.

\section{Visitor Meaning Making}

Falk and Dierking identify that "the dominant motivation for humans is meaningmaking; the need to make meaning is innate."7 Visitor meaning making is part of the

\footnotetext{
${ }^{7}$ Falk, Learning from Museums, 113.
} 
learning process, occurring in different ways during all aspects of their museum visit. Thompson recognises "visitors take meaning from museums in different ways because every visitor is different" again based on Howard Gardner's theory. Using Falk and Dierking's experience contexts we can examine the meaning making process of Campbell's experience. Campbell's meaning making experience, as accounted by him, focuses mainly on the social and physical contexts of his visit. However his personal background did influence his meaning making process. Campbell stated that he visits museums and attends dance events regularly. Campbell is also a semi-professional dancer and therefore has some knowledge of performing dance himself. Campbell had also been to the Museum of Wellington previously and so he knew what to expect from that particular museum. This personal context, previous experience in museum settings combined with his own knowledge of dance would have influenced the meaning he took from his experience as it made him more comfortable in his environment.

The physical context of the museum also influenced Campbell's meaning making. The physical environment in the museum caused interaction with other audience members, including the group he attended the event with. Campbell states that because the space was small, and also because the audience moved to the different venues as a group, he was "constantly engaging with them [the other audience members] reviewing the dance as it went". Referring again to Tarrant's comment that the dance was about "sharing space" this illustrates that the physical context of the museum, where the dance took place, influenced the meaning making process.

The social context in which Campbell attended the case study event greatly influenced the meaning he took from the experience. Throughout the interview Campbell reflects on his interactions with the people he visited the museum with. Significantly, Campbell comments that on reflection, one of his lasting memories of the event was the experience he had with his friends:

One of the people that I went with...she was killed in the Christchurch earthquake...it was actually one of the last times that I kind of really had hung out with her...it was in a way the last quality time that I'd got to spend with her. 
This shows a meaning made entirely separately from the intent the museum staff or the dance staff had for the event, yet it is in no way irrelevant. Campbell states that it was:

Kind of cool that we were able to do that in that way, and I think it was very different to if we'd just gone and seen them at a theatre. And we were able to interact and think about it, and reflect on it.

The thing that made the experience different to other dance performances, that it was in the museum environment, is what led to the social interaction which made it more meaningful for Campbell. This shows that no matter how carefully the museum has planned the experience they cannot control it entirely because every person is different and brings with them a different personal context. This particular experience allowed the audience members to talk to each other, which is different from a traditional theatre experience.

\section{Summary}

Both the museum and the dance company staff recognise that there are barriers and issues that could have prevented the event from going ahead, but all provided solutions to overcome these barriers. The first section of this chapter outlined the practical issues which must be addressed when holding dance events in a museum. The barriers that could have prevented the event from going ahead were ultimately overcome and the benefits of the event outweigh those issues. The three areas of concern identified in this chapter outline aspects of the event which were problematic for both the dance company and the museum. Safety and communication were significant issues for both institutions. Measuring the success of the event was also problematic, as different people had a different idea of what success meant for this event.

The connection between the dance piece and museum exhibition proved to be problematic. Mason recognised that visitors did not see the collaboration between the two institutions. Because the collaboration is a priority for Mason, the lack of recognition was a major concern. The interviews also highlight that there is a gap between the intent of the museum and Footnote and the audience's perception of the piece. The final section, covering the overarching reasons why the institutions hold 
these events, illustrates that despite the barriers and issues which could prevent the event from happening, there are significant positive outcomes of the event for both institutions. The next chapter, chapter four, discusses the conclusions of the research. It also includes two areas where I see potential for further development. 


\section{Chapter Five: Conclusions}

\section{Conclusions}

This research set out to investigate a case study of contemporary dance being used in a New Zealand museum in order to provide insight into the specific issues faced when incorporating dance in museums. The research was focused on investigating the practicalities of running the event, the relationship between the dance company and the museum and the impact on the visitor. These areas had not been previously investigated in a specific case study in New Zealand. Each area is discussed individually in this chapter.

Firstly, in terms of the practicalities of the event, this case study highlighted that there are significant barriers which could prevent dance being incorporated in museums. Many of these were practical barriers which affected both organisations, for example choosing a location within the museum which was suitable for the performance. Because the museum is not custom built for performance it was difficult to find a space suitable for the dancers (with, for example, wooden floors) which also provided ample room for the audience. In the end, a location was found. However while the flooring was suitable and there was space for the dancers, the audience was forced to squeeze into a smaller space. This area posed significant dangers to valuable museum objects, highlighting the numerous compromises which were made in finding a suitable location for the performance.

The relationship between the dance company and the museum was an integral part of this research. The longstanding professional relationship between the directors of both organisations has led to much collaboration between Footnote and the Museum of Wellington. Mason indicated that the collaboration between the two organisations was of the utmost importance to him. The relationship between the two organisations has continued over a number of years, despite the lack of financial return for the museum. An important aspect of this relationship was communication between those working on the event. Because all of those people involved in the event saw the importance of communication, any issues which arose were identified, discussed and resolved. 
Finally, I investigated the visitor response to the event. This revealed that no matter how well planned the event is, or how well intentioned, the visitors' own personal experience cannot be determined by those planning the event. Campbell's memories of the event are influenced by his friend's death, a factor which the museum and the dance company had no control over. While those interviewed did not recognise an obvious connection between the dance and the museum exhibition where it was located, both indicated that they interpreted it on another level by connecting and communicating with other audience members and "sharing space".

On the whole, all people involved worked through the problems which arose, in order to ensure that the event went ahead and was a success. This highlights that the value of incorporating dance in the museum is recognised by both the museum and the dance company. The event was seen as worthwhile for both institutions and as a result any challenges were overcome to ensure the success of the event.

\section{Areas for Development}

This section discusses areas where I see room for further development or investigation. Firstly, it discusses the development of museum policy specific to holding dance events in the museum. Secondly, it explores the potential for implementing visitor research at dance events.

\section{Museum Policy}

The first area of development is the potential to create a museum policy specifically concerned with performance within the museum environment. Timothy Ambrose and Crispin Paine identify that museum policy should cover the "key areas of the museum's operation" and that this includes "care and security of collections". " The Museum of Wellington does not have a specific policy regarding the protection of objects during a public performance or event of this nature. This is in part due to the longstanding relationship between the two organizations, however similar relationships do not exist with all groups coming into the museum. Regarding object safety, Stephanie Weil and Earl Cheit determine that a museum requires "closely followed policies for the acquisition and management of its collections that assure their proper physical care" and that these policies are a significant attribute of a "well-

\footnotetext{
${ }^{1}$ Timothy Ambrose and Crispin Paine, Museum Basics, (London: Routledge, 1993), 233.
} 
managed museum." ${ }^{2}$ Sufficient policy regarding object safety in the event of a public performance would come under this category as it would ensure that the object was appropriately cared for during the event. As stated earlier, Mason comments that where objects are concerned there has "never been a policy but it's been a known / unknown type of thing, everyone knows it but no one knows where it came from". On one hand, this leads to each situation being assessed on a case by case basis, which is a positive because every event is different. However it also illustrates that there is no solid policy on what is and is not appropriate within the museum regarding object safety, which could become problematic. Attfield raises the issue that there was potential for damage to the model ship, the Pamir, during the event. Attfield says that it could have been "really disastrous" because the performers potentially could have broken the model with the chair they used as a prop and he was also unsure of who is ultimately responsible for damage of that nature. In hindsight he could have asked them to move to another location to minimise the risk to the objects.

This is a specific example where there was no policy to cover a potential breakage or accident in the museum. Mason does state that he leaves those decisions up to the museum team because "they know more about it than I do", again trusting his staff to handle issues appropriately. The unknown aspects of events of this nature are perhaps what have led to an absence of set policy regarding safety. Attfield himself admits that "there's always going to be parts of it you're going to have to wing" because you cannot anticipate every facet of the performance. Mason's trust in his team to handle problems and make decisions as they arise is testament to the professionalism of all the museum staff. Fortunately during the case study no objects were damaged, however for future events the policy regarding this might be considered. Similarly, policy regarding the safety of those performing at the museum could also be useful in this situation. Injuries to dancers are likely in any situation, including the museum environment. William Boyd identifies that museums are also accountable for personnel policies. ${ }^{3}$ This would include policy regarding the safety of their staff members and people who are working in or for the museum, which would include

\footnotetext{
${ }^{2}$ Stepheanie E. Weil and Earl F. Cheit, "The Well-Managed Museum" in Reinventing the Museum: Historical and Contemporary Perspectives on the Paradigm Shift, ed. Gail Anderson, (California: Alta Mira Press, 2004), 349.

${ }^{3}$ Willard L. Boyd, "Museum Accountability: Rules, Ethics and Accreditation" in Reinventing the Museum: Historical and Contemporary Perspectives on the Paradigm Shift, ed. Gail Anderson, (California: Alta Mira Press, 2004), 352.
} 
performers. If future events of this nature were planned, a Health and Safety plan specifically for the event could be developed. Because there are so many hazards within a museum, a Health and Safety plan would be useful to identify the hazards to staff and public, as well as identifying measures to prevent accidents. Fortunately in the case study nobody was seriously injured. Hunziker did injure her foot on the wooden floor but did not feel this affected her performance.

\section{Visitor Research}

Throughout all of the interviews with those involved in organising the event, the visitor experience was discussed. However no visitor research was carried out and all comments made on the visitor experience were anecdotal and based on assumption. As previously stated, both Mason and Bayertz acknowledge that no formal visitor research was conducted, and that it would be beneficial in the future. HooperGreenhill identifies that for museums, visitor research "is regarded as essential management information". 4

In the context of the case study, visitor research could benefit both organisations in similar ways, as arts institutions face many of the same challenges in today's leisure market. Visitor research has significant implications for the marketing of events of this nature, as information collected can assist in segmenting the museums market. The book Museum Basics identifies that there are many ways of segmenting the museum's market, including by age, sex, income, education, location, leisure participation, lifestyle and patterns of use. ${ }^{5}$ Once a marketer has segmented their market, they can use the information to determine what sorts of people attended the event. When planning future events, marketers can use this information to determine who their target market is, or plan to aim marketing at those people who did not attend in order to widen their audience. This also related to audience development which is, as stated earlier, a major concern for Mason. By investigating those people who did attend the event, the research will also reveal the groups or types of people who did not attend the event. These groups of people (segment of the market) could

\footnotetext{
${ }^{4}$ Eilean Hooper-Greenhill "Studying Visitors" in A Companion to Museum Studies, Blackwell Companions in Cultural Studies 12 ed. Sharon Macdonald, 362-376, (Malden, M.A: Blackwell Publishers, 2006), 368.

${ }^{5}$ Ambrose, Museum Basics, 20.
} 
then be targeted as an audience for further development, with future events planned to attract them to the museum.

Marketers can also use visitor research to identify which types of marketing have been most effective and which have failed. Again, this has implications for future events as marketers can focus on the marketing methods they know to be successful. Audience development also has significant financial benefit for the museum. Many museums, despite receiving funding from external sources, must "generate enough income to ensure their survival." Attracting visitors to the museum is important, as they may pay to enter the museum or event and potentially spend money in the museum shop or cafe. In the context of the case study, Baeyertz states that publicity was also vital in explaining "how it's going to work" so that the audience knew what to expect at the event. Baeyertz recognises that "the audience is sort of going out on a limb when they're going to a performance at the museum." Ensuring that marketing and publicity are effective and wide reaching would also, in this situation, ensure that visitors knew what they were getting themselves into.

Visitor research can also be an opportunity to encourage people to join the organisations' mailing lists affiliated groups. Both the Museum of Wellington and Footnote have affiliated groups, for the museum the Pōneke History Club and for Footnote the Footnote Dance Devotees. These groups provide opportunities for direct marketing (through regular newsletters and online updates) as well as revenue gathered from membership fees and donations. Including information about these groups during a survey or on a self-complete survey form would raise visitor awareness. Visitors also benefit from joining these organisations as they are kept up to date with events and activities, as well as receiving invitations to various events. One of the benefits of the case study event is that both organisations can benefit from any research conducted if the data collected is shared. If the institutions were to plan to research together, then time, staffing and money could be shared between the institutions.

\footnotetext{
${ }^{6}$ McLean Marketing the Museum, 30.
} 
This case study was the first in depth investigation of a contemporary dance performance in a New Zealand museum. While it is only one, quite specific example, it provides useful insights into the benefits and challenges of incorporating dance in museums. Meanwhile, the future of dance in New Zealand museums is promising. Currently, The Museum of Wellington City and Sea is holding an exhibition called "Dancing Delights" (June-August 2011). The exhibition displays the scrapbooks and sketches of Nesta Carwell-Cooke, a New Zealand dancer and dance teacher from the early $20^{\text {th }}$ century. The exhibition juxtaposes these archives with Karen Walkers 2011 costume designs for the Royal New Zealand Ballet. Accompanying the exhibition is a two month programme of dance events, open to the public on Sunday afternoons. This series of public events incorporates a number of different types of dance, including contemporary dance, Cook Island traditional dance and classical ballet. All of the dance groups involved are local community groups and dance companies, and provide a demonstration, followed by a session for visitors to join in and learn a routine. This exhibition and the accompanying public programme illustrates scope and potential for dance within the museum. It combines dance archives with contemporary design work, and utilises a wide range of dance styles to provide a participatory experience for visitors of all ages and dance ability. The exhibition also provides the opportunity to visitors to complete an online survey to give feedback on the public programme events. This highlights the potential for visitor research to confirm the museums assumption regarding visitor attendance of these events.

This event positions the museum as the "facilitators of creativity" Thompson refers to in his interview. It also highlights the bright future of dance in museums and the opportunity for institutions to collaborate with local dance groups to provide unique and exciting dance exhibitions and events. 


\section{BIBLIOGRAPHY}

Alexander, Edward P. Museums In Motion. California: Sage, 1996.

Alivizatou, Marilena. "Intangible heritage and the performance of identity" in Performing Heritage: Research, Practice and Innovation in Museum Theatre and Live Interpretation. ed. Anthony Jackson and Jenny Kidd,89-90, Manchester: Manchester University Press, 2011.

Ambrose, Timothy and Paince, Crispin. Museum Basics. London: Routledge, 1993.

Bennett, Tony. The Birth of the Museum: history, theory, politics. London:Routledge, 1995.

Black, Graham. The Engaging Museum: Developing museums for visitor development, New York: Routledge, 2005.

Blocker Bowers, Dwight. “And Now for Something Completely Different:

Reconstructing Duke Ellington's Beggar's Holiday for Presentation in a Museum Setting" in Exhibiting Dilemmas: Issues of Representation at the Smithsonian. ed. Amy Henderson and Adrienne L. Kaeppler, 262-272, USA:Smithsonian Institution, 1997.

Boyd, Willard L. "Museum Accountability: Rules, Ethics and Accreditation" in Reinventing the Museum: Historical and Contemporary Perspectives on the Paradigm Shift, edited by Gail Anderson, 351-352. California: Alta Mira Press, 2004.

Bruce, Chris. "Spectacle and democracy: Experience Music Project as a PostMuseum" in New Museum Theory and Practice: An Introduction. ed. J Marstine, UK: Blackwell, 2006. 
Buckland, Teresa. "Traditional dance: English ceremonial and social forms" in Dance History: An Introduction. edited by. Janet Ashead-Lansdale and June Layson, 45-58. London:Routledge, 2004.

Creswell, J. Research Design: Qualitative, Quantitative and Mixed Methods. California: Sage, 2009.

"Convention for the Safeguarding of the Intangible Cultural Heritage". (accessed19/5/2011) http://unesdoc.unesco.org/images/0013/001325/132540e.pdf

"Dance in the New Zealand Curriculum" (accessed 1/6/2011) http://www.tki.org.nz/r/arts/curriculum/statement/dance_curric_e.php

Dils Ann, and Cooper Albright, Ann. moving history / dancing cultures: A Dancer History Reader. Middletown, Connecticut: Wesleyan University Press, 2001.

Falk, John H. and Dierking, Lynn D. Learning from Museums. California:Altamira Press, 2000.

Falk, John H. and Dierking, Lynn. D. The Museum Experience. Washington: Whalesback Books, 1994.

Fludernik, Monika. An Introduction to Narratology. New York: Routledge, 2009.

Foley, M and McPherson, G. "Museums as Leisure" International Journal of Heritage Studies Vol. 6, No.2,(2000)161-174.

Glass, Renee. “Observer Response to Contemporary Dance” in Thinking in Four Dimensions: Creativity and Cognition in Contemporary Dance. edited by Robin Grove, Catherine Stevens, Catherine and Shirley McKechnie, 107-121. Melbourne: Melbourne University Press, 2005. 
Guest, Ann Hutchinson. Dance Notation: The Recording of Movement on Paper. New York: Dance Horizons, 1984.

Herman, David., Jahn, Manfred and Marie-Laure Ryan, Marie-Laure, eds, Routledge Encyclopedia of Narrative Theory. New York: Routledge, 2005.New York: Dance Horizons, 1984.

Heumann Gurian, Elaine, "What is the object of this exercise? A meandering exploration of the many meanings of objects in museums". Humanities Research, 8,1,(2001): 25-36 accessed 25/6/2011. url:http://proquest.umi.com/pqdweb?did=44467215\&sid=5\&Fmt=3\&clientId= 7511\&RQT $=309 \& \mathrm{VName}=\mathrm{PQD}$.

Hooper-Greenhill, Eilean. Museums and their Visitors. London: Routledge, 1994.

Hooper-Greenhill, Eilean. "Education, Communication and Interpretation: Towards a critical pedagogy in museums" in The Educational Role of the Museum, $2^{\text {nd }}$ Edition. 3-27. Routledge, London, 1999.

Hooper-Greenhill, Eilean. "Communication in theory and practice" in The Educational Role of the Museum, $2^{\text {nd }}$ Edition, 28-43. Routledge, London, 1999.

Hooper-Greenhill, Eilean. Museum and the Shaping of Knowledge. London: Routledge, 1992.

Hooper-Greenhill, Eilean. "Studying Visitors" in A Companion to Museum Studies, Blackwell Companions in Cultural Studies 12. ed. Sharon Macdonald, 362376. Malden, MA: Blackwell Pub, 2006. 
Humphrey, Doris. “America's Modern Dance”, in The Dance Experience. eds. Myron Howard Nadel and Constance Gwen Nadel, 105-109New York: Praeger Publishers.

Jackson, Anthony and Jenny Kidd, ed. Performing Heritage: Research, Practice and Innovation in Museum Theatre and Live Interpretation. Manchester: Manchester University Press, 2011.

Kotler, N. ""New ways of Experiencing Culture" the Role of Museums and Marketing Implications" Museum Management and Curatorship 19, 4 (2001): 417-425.

Kotler Neil and Kotler, Phillip. "Can Museums Be All Things to All People?: Missions, Goals and Marketing's Role." Museum Management and Curatorship. 18, no. 3 (2010): 271-287.

Kraus, Richard. History of the Dance in Art and Education. Englewood Cliffs, New Jersey: Prentice-Hall Inc.,1969.

Lewis, Sally. April 5th, 2011. “Guest post: Sally Lewis on Music, Movement and Machinery at the Museum of Bath at Work" (acessed 17/6/2011) http://museumsatnight.wordpress.com/2011/04/05/guest-post-sally-lewis-onmusic-movement-and-machinery-at-the-museum-of-bath-at-work/

Lockstone, Leonie. "Major Case Study" Shape shifters - the role and function of modern museums" in Museum Marketing: Competing in the Global Marketplace. ed Ruth Rentschler and Anne Marie Hede, Oxford:Elsevier Ltd.,2007.

McFee, Graham. Understanding Dance. London:Routledge, 1992.

Mead, Hirini Moko. Tikanga Maori: Living by Maori Values. Wellington: Huia Publishers, 2003. 
Mitra, Royona "Performing cultural heritage in Weaving Paths by Sonia Sabri Dance Company", In Performing Heritage: Research, Practice and Innovation in Museum Theatre and Live Interpretation. ed. Anthony Jackson and Jenny Kidd,144-157. Manchester: Manchester University Press, 2011.

McLean, Fiona. Marketing the Museum. London: Routledge, 1997.

Nadel, Myron Howard and Nadel,Constance Gwen, eds. The Dance Experience: Readings in Dance Appreciation. New York: Praeger Publishers, 1971.

"National Museum of Dance", accessed 15/5/2011 http://www.dancemuseum.org/index.html

Piper, Heather and Simons, Helen. "Ethical Responsibility in Social Research" in Research Methods in the Social Sciences. ed. Bridget Somekh and Cathy Lewin, 56-64. London: Sage, 2005.

Rentschler, Ruth and Hede, Anne-Marie, eds, Museum Marketing: Competing in the Global Marketplace. Oxford: Elsevier Ltd., 2007.

Ruggles, D. F. and H. Silverman, From Tangible to Intangible Heritage. Intangible Heritage Embodied. New York: Springer, 2009.

Ryan, P.M. The Reed Dictionary of Modern Maori. Auckland: Reed Books, 1997.

Sarantakos, Sotorios. Social Research. Basingstoke, Hampshire: Macmillan Press Ltd., 1993

Scheff, Joanne and Kotler, Phillip. Standing Room Only: Strategies for Marketing the Performing Arts. Boston: Harvard Business school Press, 1997.

Somekh, Bridget and Lewin, Cathy. Research Methods in the Social Sciences. London: Sage, 2005. 
Weil, Stephanie E and Cheit, Earl F. "The Well-Managed Museum" in Reinventing the Museum: Historical and Contemporary Perspectives on the Paradigm Shift. Ed. Gail Anderson, 348-350. California: Alta Mira Press, 2004.

Stevens, Catherine, "Trans-disciplinary Approaches to Research into Creation, Performance and Appreciation of Contemporary Dance" in Thinking in Four Dimensions: Creativity and Cognition in Contemporary Dance. ed. Robin Grove, Catherine Stevens and Shirley McKechnie, 154-168. Melbourne: Melbourne University Press, 2005.

Tapsell, Paul. "The Flight of Pareraututu: An Investigation of Taonga from a Tribal Perspective." The Journal of the Polynesian Society 106, no. 4 (1997): 323-74.

Timothy, D.J and Boyd, S.W. Heritage Tourism. New York: Pearson Education, 2002.

Weaver, Stephanie. Creating Great Visitor Experiences. California: Left Coast Press, 2007.

“White Lodge Museum and Ballet Resource Center" (accessed 15/5/2011) http://www.royal-ballet-school.org.uk/wl_museum.php?s=1

Wilkinson, T.M. "The core ideas of research ethics" in Research Ethics in Aotearoa New Zealand: Concepts, Practice, Critique. edited by M. Tolich, 13-23. Auckland: Longman, 2001. 


\section{Appendices}

\section{Appendix A: Interview Schedules}

\section{OVERARCHING INTERVIEW GUIDE -MUSEUM STAFF}

What is your position in the museum?

What was your role in the planning / hosting of this event?

Have you ever been involved in a similar event?

What were your expectations of the performers / dance staff? (Regarding object safety, practical issues etc.)

Does the museum have planning / procedures already in place for these types of events?

What were your major concerns (if any) with having dance in the museum?

Do you feel that the event was successful?

Did you deal with any unexpected problems / situations that arose during the event?

How did you resolve them?

Would you be interested in holding another similar event in the future?

\section{OVERARCHING INTERVIEW GUIDE - DANCE STAFF}

What is your background with the company?

What was your role in the event?

Did you have any role in organising / planning the event?

Have you ever been involved in a similar event?

What were your expectations of the museum? (Regarding facilities, safety etc. practical issues)

Did you feel the event was successful? Why/ Why not?

Did you deal with any unexpected problems / situations that arose during the event?

How did you resolve them?

Would you be interested in participating another similar event in the future?

Is there anything else you would like to add?

\section{FOR DANCERS ONLY}

Do you feel comfortable performing a non specific place? 
What challenges did you face in an environment like this?

How did you feel about dancing in the museum space?

\section{INTERVIEW GUIDE - AUDIENCE MEMBER}

How did you hear about the event?

Why did it appeal to you?

Had you been to see Footnote before?

Would you usually go to see contemporary dance?

Had you been to the Museum of Wellington before?

Would you usually visit museums?

Thinking about the event at the museum of Wellington specifically...

Who did you attend the event with?

Did you spend much time looking at the exhibitions before/after the dance?

Did you enjoy this?

Were there any downsides to having the event at the museum?

Were there any parts you didn't enjoy? Why?

Did you think the event was successful?

Would you go to a similar event?

Would you recommend it to friends? 


\section{MEMORANDUM}

\begin{tabular}{l|l}
\hline TO & Naiomi Murgatroyd \\
\hline COPY TO & Lee Davidson \\
\hline FROM & Dr Allison Kirkman, Convener, Human Ethics Committee \\
\hline
\end{tabular}

\begin{tabular}{l|l}
\hline DATE & 19 November 2010 \\
\hline PAGES & 1 \\
\hline SUBJECT & $\begin{array}{l}\text { Ethics Approval: No 18098 Moving Museums: Incorporating } \\
\text { Dance in New Zealand Museums }\end{array}$ \\
\hline
\end{tabular}

Thank you for your application for ethical approval, which have now been considered by the Standing Committee of the Human Ethics Committee.

Your application has been approved from the above date and this approval continues until 31 March 2011. If your data collection is not completed by this date you should apply to the Human Ethics Committee for an extension to this approval.

Best wishes with the research.

Allison Kirkman 


\section{Appendix C: Interview Invitation}

\section{Incorporating Dance in New Zealand Museums}

Researcher: Naiomi Murgatroyd, Museum \& Heritage Studies Programme, Victoria University of Wellington

Hello,

I am a Masters student in the Museum and Heritage Studies at Victoria University of Wellington. I am conducting research as part of the requirements of my dissertation, and I would like to invite you to participate.

I am researching for a dissertation investigating the use of dance in New Zealand museums, in particular the practical issues involved in undertaking dance events in museum spaces. You have been invited to participate as you are in some way involved in the process of holding a dance event in a museum. If you agree to participate, this will involve meeting me for an interview to discuss the dance event and your involvement in it.

In particular we will discuss your expectations and experiences in the lead up to the vent, how you were involved in the event personally and your experiences during the event. The meeting can take place at a location convenient to you at a mutually agreed upon time, and should last about one hour or so. With your permission, the interview will be recorded for my use so that I can review the information you provide. The recording will be transcribed and sent to you for checking and editing before being reviewed by myself.

Due to the nature of the investigation anonymity is not possible, however all information and opinions will be treated sensitively and you will have the opportunity to correct, add or delete anything you have provided as mentioned above. The results of the research will be discussed in my dissertation but all recordings and related material will be kept in a secure location. No other person besides my supervisor, $\mathrm{Dr}$ Lee Davidson, and I will have access to the data. Recordings and transcripts will be destroyed once the dissertation has been marked.

Should you feel the need to withdraw from the project, you may do so without question at any time before the $30^{\text {th }}$ of November 2010. You may also decide not to answer any question you are not comfortable with. The VUW Human Ethics Committee has granted approval for this project.

The dissertation will be submitted for marking to the Museum and Heritage Studies Programme and will be deposited in the University Library. I will be happy to answer any questions you have about the study. You may contact me at murgatnaio@myvuw.ac.nz, or my research supervisor, Lee Davidson, lee.davidson@vuw.ac.nz if you have course related questions or problems. 
Thank you for your consideration. I will call you within the next week to see whether you are able to participate.

Kind regards,

\section{Naiomi Murgatroyd}

0273167172

murgatnaio@myvuw.ac.nz

Lee Davidson

Senior Lecturer

Museum \& Heritage Studies

044635929

lee.davidson@vuw.ac.nz 


\section{Appendix D: Consent Form \\ CONSENT TO PARTICIPATION IN RESEARCH}

\section{Title of project: \\ Incorporating Dance in New Zealand Museums}

I have been given and have understood an explanation of this research project. I have had an opportunity to ask questions and have them answered to my satisfaction. I understand that I may withdraw myself (or any information I have provided) from this project before the $30^{\text {th }}$ of November 2010 without having to give reason.

I understand that any information I provide will be kept confidential to the researcher and the supervisor, and that I will have an opportunity to check the transcripts of the interview before publication. I also understand that the published results will use my name and my opinions will be attributed to me.

I understand that the tape recording of interviews will be electronically wiped at the end of the project and the data I provide will not be used for any other purpose or released to others without my written consent.

I would like to receive a summary of the results of this research when it is completed. Yes/No

If Yes, please provide email address:

I agree to take part in this research

Name of participant (please print clearly):

Signed:

Date: 
Appendix E: Excerpt from Museum of Wellington City and Sea Policy

Suite

\section{EDUCATION POLICY}

INTRODUCTION

Education in its broadest sense is woven into the every aspect of the visitor's 'museum experience'. The desire to know and understand encourages people to explore and engage with collections and the stories they tell, for inspiration, enjoyment and lifelong learning. The role of the Museum's education service is to contribute to a high quality, seamless museum experience for all visitors.

Education may be broadly categorised into formal and informal learning. Formal learning is closely linked with school curricula and the New Zealand Curriculum framework with guided programmes tailored to meet specific needs of teachers and students. Conversely, informal learning encourages individuals to discover and absorb the collection and the stories it tells and to take from this experience whatever they want in whatever way they choose.

Formal and informal facets of education coexist: informal learning is part of any formalised programme, and some degree of formal learning is likely to occur during an unstructured visit.

The delivery of education in all its guises is at the 


\section{heart of the museum's operation. It requires the support of all staff in all departments to work together to create an environment which is stimulating and encourages exploration and discovery, yet is friendly and welcoming on a personal level.}

\section{The Education Coordinator and Service}

The education coordinator has three broad functions:

1. To deliver formal education programmes

2. To be part of the exhibition development team to ensure that formal and informal educational opportunities are maximized

3. To help organise, deliver and contribute to informal education, such as holiday programmes, public programmes, and special events.

The Education Service contributes to:

1. Ensuring that the museum is accessible to all audiences in the community, regardless of age, sex, ability, disability, social, ethnic /or religious background by:

- Being part of exhibitions team to deliver Interactive 'hands on' exhibitions and temporary exhibitions

- Organising public lectures, holiday programmes and special events targeted at a variety of audiences

- Providing education service workshops, curriculum linked visits, focus sheets, handling sessions, newsletters, teacher previews, teacher information packs, videos and resources and teacher trainee placements

2. Promoting the value of museums as centers for life- long learning by:

- Initiating visits and outreach programmes

- Producing regular newsletters

- Supplying Information packs

- Undertaking follow-up evaluations after formal education sessions

- Offering trainee teacher places from time to time 
3. Ensuring all Museum of Wellington City and Sea staff members are aware of the important role of education in the development and delivery of the museum service by:

- Communicating issues positively and in a timely manner through meetings and staff meetings

- Contributing professionally to the exhibition development team

- Sharing knowledge and skills freely both formally and informally

4. Providing a high quality seamless museum experience, in terms of customer care, exhibition programmes and resource provision by:

- Helping to deliver high quality exhibitions

- Providing the highest quality of customer care

- Listening to and acting on customer feedback.

5. Delivering successful and stimulating public programmes by:

- Helping to ensure they are relevant to the museum and its audiences.

- Providing a wide range of opinions and perspectives.

- Making programmes and activities interesting to suit a range of audiences from the scholarly to the recreational.

6. Provide formal education programmes to schools and assist teachers in using the museum as a place of learning by:

- Provision for an Education Coordinator.

- Creation and delivery of NZ curriculum linked programmes.

- Provision of relevant and up to date resources.

7. Being at the forefront of museum theory and practice in delivering challenging formal and informal learning experiences to the community by:

- Establishing appropriate professional networks

- Seeking and engaging in appropriate staff training opportunities. 
8. Encouraging of public groups using the museum's facilities for educational purposes and to present programmes by:

- Being receptive to approaches from community/interest groups.

- Promotion of any scheduled events and activities where appropriate.

9. Making the Museum's collection as physically and intellectually accessible as museum resources permit by:

- Using collections during education programmes when possible

- Using collections when creating resources when appropriate

- Actively contributing ideas for use of the collection in other areas of museum operations.

\section{SUMMARY}

Education is at the heart of our museum's operation. The education service is therefore involved at almost every level of the organisation to provide expertise, help or to deliver on its own specific objectives. Learning, whether it is formal or informal, is part of every visitor's experience - it is the role of the Education Service to ensure that the opportunity for visitors to engage and learn is maximized. 


\section{Appendix E: Excerpt from Wellington Museums Trust Statement of Intent,}

\section{0-2011- Page 19}

\section{Council Relationship Principles}

The Local Government Act 2002 requires local authorities to promote the cultural well-being of their communities. Funding of arts and cultural institutions is one way in which they meet this requirement.

However, it is important that the Trust is accountable for the ratepayer funds it is allocated and that the purpose of the Trust to provide visitor experiences and manage heritage collections is an effective and efficient use of these funds.

The Trust will provide quarterly reports in the agreed format to the Monitoring Subcommittee on the

agreed dates and present its Statement of Intent on the agreed date. The Trust's Annual Report and

audited accounts will be supplied to Council within 60 days of the end of the financial year.

The principles governing the relationship with Council as its primary stakeholder will include:

Operating on a "no surprises" basis with open and full disclosure of information as required.

Early advice to Council in the event of any situation that may be potentially contentious in nature.

$\neg$ Disclosing within the Trust's Business Plan any significant transactions that are planned.

\section{Alignment with Council's vision and strategic priorities}

Trust institutions are well placed to contribute to Council's vision which is to position Wellington as vibrant, internationally competitive and affordable and to support its strategic priorities, particularly for

cultural well-being which places emphasis on shaping Wellington's unique identity, by:

$\square$ Taking a more pro-active role in protecting and enhancing local sense of place.

$\checkmark$ Strengthening the Council's partnerships with arts organisations, festival groups and institutions.

$\neg$ Engaging more effectively with the community on the benefits and relevance of a diverse city.

$\neg$ Engaging more effectively with grassroots, community and youth-orientated arts and cultural activities.

Many of the Trust's activities link directly to the Council's priorities. Refer to Appendix 5 for details.

\section{Full document available at www.wmt.org.nz}

